\title{
Women, Sheep, and Textiles: The social significance of ram's head beads in Early Iron Age Slovenia
}

\author{
Ženske, ovce in tekstil: \\ družbeni pomen jagod $v$ obliki ovnove glavice \\ v starejši železni dobi na Slovenskem
}

\author{
Adrienne C. FRIE
}

\begin{abstract}
Izvleček
Jagode v obliki ovnove glavice sodijo med dobro znane nakitne predmete dolenjske halštatske kulturne skupine. S 187 doslej odkritimi primerki so na tem območju najpogostejše zoomorfne najdbe, kot je pokazala nedavna analiza. V prispevku je posodobljen seznam tovrstnih jagod in kontekstualiziran njihov pomen v tej kulturni skupini. Predstavljeni so argumenti za tezo, da so upodobitve ovac/ovnov v obliki jagod in njihovo pojavljanje v ženskih grobovih povezani z lokalno tekstilno dejavnostjo. Pripisati jim je mogoče vlogo označevalca osebne in ekonomske identitete dolenjskih halštatskodobnih žensk, povezano z izdelovanjem visokokakovostnih tkanin. Poleg tega kaže razprostranjenost teh jagod na mrežo tesnih stikov med najdišči na zahodnem obrobju teritorija dolenjske železnodobne skupnosti, morda odslikava celo mobilnost žensk med lokalnimi skupnostmi.
\end{abstract}

Ključne besede: jugovzhodna Slovenija; starejša železna doba; dolenjska halštatska kultura; jagode v obliki ovnove glavice; ikonografija; ženske; ovce; tekstil

\section{Abstract}

Ram's head beads are well-known items of personal adornment in the Dolenjska Hallstatt cultural group. Recent analysis has demonstrated that they are the most common zoomorphic artefacts in this region with 187 currently known. This article updates the list of known beads and contextualizes their significance in the Dolenjska Hallstatt cultural group. It is argued that the sheep imagery of these beads and their distribution in female graves is related to local textile production. It is proposed that beads signalled aspects of personal and economic identity for Dolenjska Hallstatt women related to the production of high-quality textiles. In addition, the distribution of these beads demonstrates Iron Age community networks on the western frontier of Dolenjska, and perhaps even reflects the movement of women between communities.

Keywords: South-eastern Slovenia; Early Iron Age; Hallstatt culture; ram's head beads; iconography; women; sheep; textiles

Ram's head beads are the most common zoomorphic artefacts associated with the Dolenjska Hallstatt cultural group of south-eastern Slovenia with one hundred and eighty-seven currently known. Markus Egg wrote the seminal piece on ram's head beads in Slovenia, assessing their production, chronology and distribution, and proposing a typology. His work remains a valuable resource, and here I will supplement this work by noting additional examples of these beads and refining 
his typology. My primary focus in this article is to delve into the question he left open ${ }^{1}$ - what was the local significance of ram's head beads?

Several broader questions frame the significance of these artefacts. First, why were sheep chosen to ornament these particular items? Sheep are not very intelligent and they do not usually make good pets or companions, at least not compared to other contemporary domesticates like dogs and horses. ${ }^{2}$ Nor do they have the clear cosmological associations such as birds and horses possessed. ${ }^{3}$ What was it about sheep? And why glass beads, which are virtually the only artefact type and medium depicting sheep in this cultural context? Finally, how can we explain the fact that ram's head beads are almost exclusively associated with women in mortuary contexts?

It is proposed that the significance of ram's head beads was linked to the importance of woolproducing sheep and textile manufacture in the Early Iron Age, which based on mortuary and iconographic evidence, was dominated by women. The evidence supporting this argument includes the distribution of ram's head beads as well as the association between ram's head beads and textile equipment such as spindle whorls recovered from Dolenjska Hallstatt period graves. To frame this evidence, I contextualize the local importance of sheep in the Early Iron Age and focus in particular on evidence for textile production. My conclusions focus on the social significance of ram's head beads for signalling aspects of personal and economic identity. It is proposed that the distribution of ram's head beads reflects community networks linked by the exchange of these items and potentially also the movement of women between Dolenjska Hallstatt communities.

\section{DISTRIBUTION OF RAM'S HEAD BEADS}

The Dolenjska Hallstatt cultural group demonstrates social stratification in the distribution of grave goods, and increasing participation in

\footnotetext{
1 Egg 2010, 539.

${ }^{2}$ Frie 2018a; Škvor Jernejčič, Toškan 2018.

${ }^{3}$ Birds and horses played a role in solar cults in Bronze and Iron Age Europe and were believed to draw the sun through the sky (Pare 1989; Kaul 1998; Kuzmina 2006; Hänsel 2012; Potrebica 2012; Teržan 2013; Bilić 2016; Frie 2018b).
}

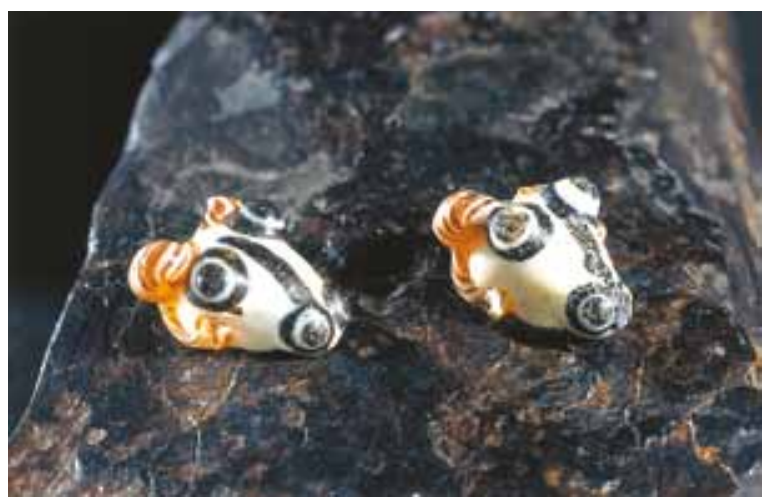

Fig. 1: Glass ram's head beads from Grave VII/28 at Kapiteljska njiva in Novo mesto.

Sl. 1: Steklene jagode v obliki ovnove glavice iz groba VII/28 na Kapiteljski njivi v Novem mestu.

(After / Po Križ, Stipančić, Škedelj Petrič 2009, 101)

long-distance trade networks. ${ }^{4}$ One aspect of this group that differentiates it from previous Urnfield practices as well as neighbouring archaeological cultures is the significant increase in the production of figural imagery, including the well-known situla art. The term refers to a style of figural imagery produced by incising and repoussé on sheet bronze objects. ${ }^{5}$ However, in addition to situla art there was also the frequent production of imagery in other styles and media, and these figural artefacts most often depict animals. ${ }^{6} \mathrm{My}$ doctoral thesis assessed Dolenjska Hallstatt animal imagery focusing on the species depicted, the types of artefacts depicting animals and their contextual associations, and the human-animal interactions that characterized Early Iron Age life. ${ }^{7}$

Ram's head beads are small glass beads between 1.1 and $2.3 \mathrm{~cm}$ in length, usually made of several colours of glass (Fig. 1). The beads depict solely the head of the ram, with eyes and nostrils elaborated by alternating layers of light and dark colours. The horns are made of twisted glass, often composed of multiple colours as well. The back of the bead has a loop for suspension. Occasionally the bead is elaborated with a stripe down the nose, glass dots on the loop, or very rarely ears. One hundred and eighty-seven ram's head beads have been identified thus far at seventeen sites (Fig. 2). There are 29 graves with a total of 104 ram's head beads, two

4 Gabrovec 1976; Dular 2003; 2020; Dular, Tecco Hvala 2007.

${ }^{5}$ Lucke, Frey 1962; Eibner 1981; Turk 2005; Križ 2012.

6 See A. Dular 1978; Tankó 2005; Metzner-Nebelsick 2007; Egg 2010; Teržan 2012; Frie 2017; 2018a; 2018b; 2019.

7 Frie 2017. 


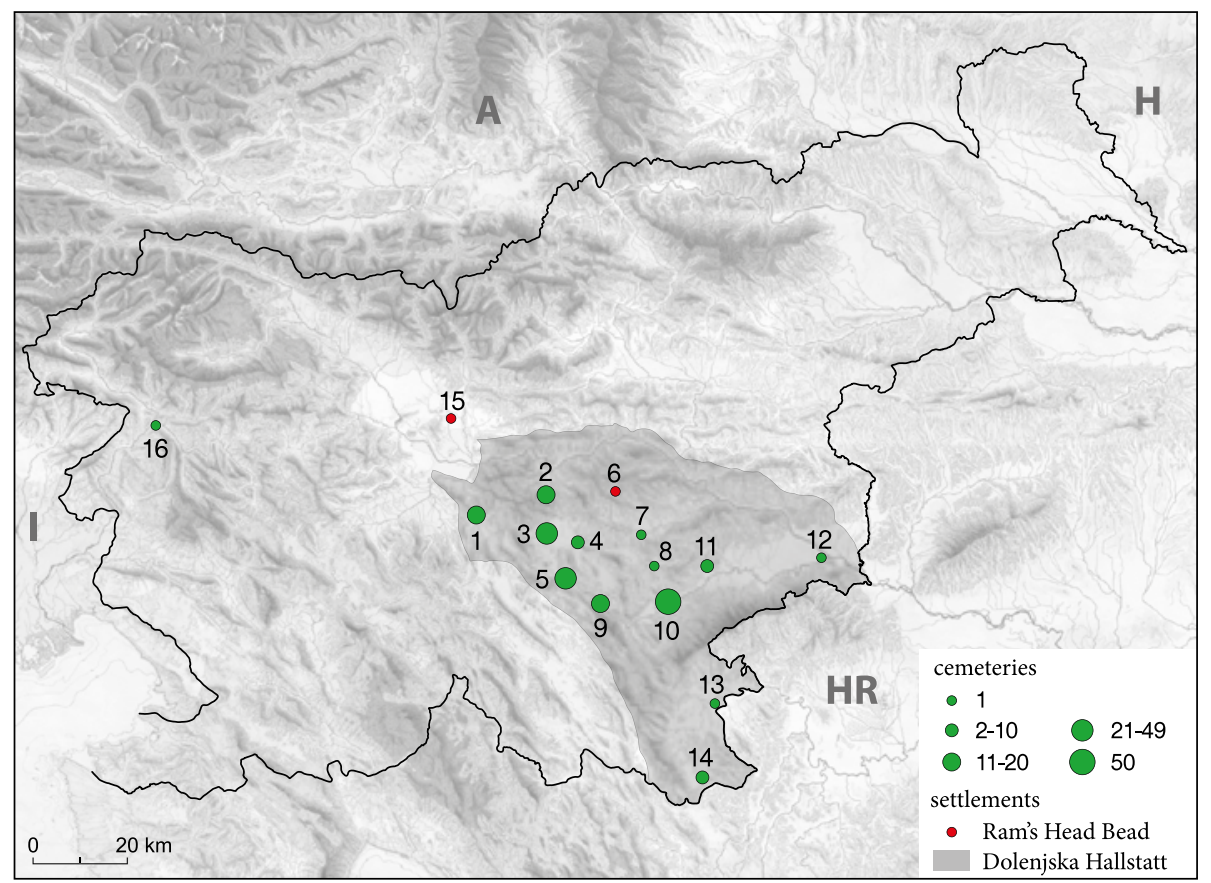

Fig. 2: Sites with ram's head beads.

Sl. 2: Najdišča jagod v obliki ovnove glavice.

\author{
1 Magdalenska gora - Preloge \\ 2 Vintarjevec \\ 3 Stična \\ 4 Medvedjek \\ 5 Valična vas \\ 6 Špičasti hrib
}

7 Volčje njive
$\mathbf{8}$ Brezje pri Trebelnem
$\mathbf{9}$ Vinkov vrh
$\mathbf{1 0}$ Novo mesto - Kandija (Znančeve njive)
and / in Kapiteljska njiva
$\mathbf{1 1}$ Vinji vrh

7 Volčje njive

9 Vinkov vrh

and / in Kapiteljska njiva

11 Vinji vrh

\author{
12 Velike Malence \\ 13 Podzemelj - Steljnik (Grm) \\ 14 Vinica \\ 15 Mengeš - Gobavica \\ 16 Most na Soči - Repelc
}

beads come from settlement contexts, and the final 81 are stray finds from mortuary contexts or other finds of unknown provenience (App. 1).

As Markus Egg previously discussed, ram's head beads from Slovenia date primarily from the second half of the Early Iron Age and into the Late Iron Age. In terms of the relative chronology for the Dolenjska Hallstatt cultural group these beads first appeared in the Certosa Fibulae phase and continued to be used in the Negova Helmets phase (i.e., late $6^{\text {th }}$ century to the end of the $4^{\text {th }}$ century BC). ${ }^{8}$ There is one La Tène grave at Kandija ${ }^{9}$ in Novo mesto that has a ram's head bead, however this is thought to be an heirloom. ${ }^{10}$

${ }^{8}$ Egg 2010, 532-535. For the relative chronology see Teržan 2008, 273-293.

9 The site name Kandija is used throughout this article since the site has been extensively published by the Dolenjski muzej under this name. However, Znančeve njive is the name of the site used in the Archaeological Cadastre of Slovenia (ARKAS, ZRC SAZU, Inštitut za arheologijo) and some other publications (ANSl 1975; Dular, Tecco Hvala 2007).

${ }^{10}$ Grave 56: Križ 2001, 164, cat. no. 542; Egg 2010, 533-534.
Work by Thea Elisabeth Haevernick and later by Borut Križ and colleagues has demonstrated that the stylistic similarity and the distribution of glass ram's head beads, as well as the preponderance of glass artefacts overall, indicates that these items were locally crafted at a glass working centre in the area of modern Novo mesto. ${ }^{11}$ New evidence indicates that while glass items were probably worked locally, glass ingots were most likely coming from the Levant or possibly Egypt. Early Iron Age glass in this region is all natron glass based on recent PIXE, PIGE analyses, and the nearest sources of natron carbonate mixtures occur in Egypt and the Middle East. ${ }^{12}$ This new data adds support for Markus Egg's hypothesis that the Dolenjska ram's head beads were inspired by earlier Mediterranean and Egyptian examples. ${ }^{13}$

While the vast majority of ram's head beads are made of glass, there are also five ram's head beads

${ }^{11}$ Haevernick 1974; Križ, Turk 2003, 78; Bakarić, Križ, Šoufek 2006, 11; Egg 2010, 534.

12 Šmit, Laharnar, Turk 2020.

${ }^{13}$ Egg 2010, 535-539. 
carved from amber in the Dolenjska cultural group. ${ }^{14}$ A pair was deposited in Grave VI/4 at Novo mesto - Kapiteljska njiva and another pair was recovered from Grave 5/11 at Stična, both dating from the $5^{\text {th }}-4^{\text {th }}$ centuries BC. ${ }^{15}$ An additional amber ram's head bead was recovered as a stray find from $\mathrm{Tu}$ mulus VI at Stična. ${ }^{16}$ Analysis of individual amber artefacts found in Dolenjska has demonstrated that this amber came from the Baltic like the majority of European amber dating to the Iron Age. ${ }^{17}$ There has been no unworked amber recovered from Novo mesto where amber is most common, and based on the current evidence it seems that amber was imported to the Dolenjska region from Italy already shaped rather than in its raw form. ${ }^{18}$

There is a single bronze ram's head bead from Grave VII/1 at Brezje pri Trebelnem. This is the only bronze ram's head bead in the area and it is the reworked foot of a crossbow Certosa fibula ${ }^{19}$ like those from Magdalenska gora described below. The burial contained typical male artefacts including two iron axes and a bronze belt plate and fittings, and as well as less clearly gendered artefacts such as a hollow bronze torque with large, spherical terminals, a necklace made of glass beads, a bronze bracelet, four bronze Certosa fibulae, ${ }^{20}$ and a cylinder of sheet bronze that was later identified as part of a sceptre. ${ }^{21}$ Several features of this grave set it apart: the torque and sceptre, as well as a large amount of animal iconography including two Certosa fibulae with horse protomes, a bronze bracelet ${ }^{22}$

\footnotetext{
14 Egg 2010, 532.

15 Novo mesto - Kapiteljska njiva VI/4: Križ, Turk 2003, 99, cat. no. 84; Bakarić, Križ, Šoufek 2006, 186, cat. no. 269. Stična 5/11: Kruh 2008, 99.

16 Wells 1981, 80, 213 Fig. 161i, though it is incorrectly identified as glass in the original publication.

17 Križ, Turk 2003, 76; Bakarić, Križ, Šoufek 2006, 131.

18 Palavestra 1993, 291-292; Bakarić, Križ, Šoufek 2006,131 . Though it has been proposed that there was limited amber working in Dolenjska based on the find of an unfinished amber bead depicting four bird heads and the amber ram's head beads which are quite similar to locally-made glass examples (Križ 2017, 41).

19 Thanks to prof. Mitja Guštin for bringing this to my attention.

${ }^{20}$ Kromer 1959, 22-23, Pls. 20; 21; Dular, Križ 1990, 538.

21 Tecco Hvala 2012, 338.

22 This find has been published as an anklet (Kromer
} 1959, 22-23; Dular, Križ 1990, 538); however, the overlapping form with a snake head terminal has much more in common with bracelets in this area (e.g., Novo mesto - Kapiteljska njiva Grave III/2, Stična Grave VII/7, Brezje pri Trebelnem Graves VII/8 and VII/28). While its size is somewhat large for a bracelet at $10.3 \mathrm{~cm}$, it could have with overlapping snake's head terminals, ${ }^{23}$ and the aforementioned bronze ram's head bead.

Ram's head beads in the Dolenjska Hallstatt culture are predominantly associated with women (Fig. 3). ${ }^{24}$ Sixty-eight ram's head beads are associated with 12 female graves. ${ }^{25}$ There is wide variation in the number of beads deposited in graves: single ram's head beads were deposited in $52 \%$ of intact graves and appear in sets of five or more in 31\% of the known graves. Grave 2 at Vintarjevec had the largest number with 14 ram's heads beads that were part of a necklace with other glass and amber beads, glass rings, and flat bone beads (Fig. 4). ${ }^{26}$

Marcus Egg previously developed a tripartite typology of ram's head beads. He distinguished between large beads of up to $2.3 \mathrm{~cm}$ in length

been worn higher up as an armlet (see Tecco Hvala 2012, 290 for a discussion of the size ranges of annular jewelry). Novo mesto - Kapiteljska njiva Grave III/2: Knez 1986, Pl. 23; Stična Grave VII/7: Wells 1981, 215 Fig. 166; Brezje pri Trebelnem Graves VII/8 and VII/28: Kromer 1959, Pl. 23 and 47, Dular, Križ, 1990, 539.

${ }^{23}$ It should also be noted that while the items in this grave seem reliable, some of the grave inventories from Brezje pri Trebelnem may be mixed and it is wise to treat this site with caution (see Božič 2018, 189 fn. 60; Laharnar 2018, 200).

24 Egg 2010.

${ }^{25}$ It should be noted that I am referring to gender rather than sex. Due to acidic soils in this region, skeletal remains rarely preserve to allow the determination of biological sex. In lieu of knowing the sex of the individual, grave goods have been used to estimate the probable gender of the deceased. In the rare cases where osteological remains have been preserved and analyzed it has been determined that certain artefacts are strongly associated with males or females and it seems that biological sex and social gender overlap and are organized in a largely binary fashion (Dolinar-Osole 1956; Gabrovec 1956; 2006; Angel 1968; Hencken 1978; Teržan 1985; Tecco Hvala, Dular, Kocuvan 2004). The larger study of animal imagery on Dolenjska Hallstatt artefacts included many artefacts that are often used to identify gender (e.g., bracelets and beads; Teržan 1985; 2008; Tecco Hvala 2012, 376-384), so to avoid circular reasoning a more conservative assemblage of artefacts was used to identify the probable gender of the deceased. Probable males were identified based on the presence of weapons, defensive gear, razors, and whetstones (Teržan 1985; 2008; 233-245; Tecco Hvala 2012, 137-143, 341), while probable females were identified based on the presence of anklets, textile equipment, earrings, and hair rings (Tecco Hvala 2007; Tecco Hvala 2012, 290, 332-333). In cases where male and female gendered artefacts appeared together in a grave without any indication that it was a multiple burial, gender attribution was marked 'indeterminate'. See Frie 2017, 76-80 for additional discussion.

26 Starè 1953, 270, Pl. IV: 1. 
and smaller beads averaging $1.5 \mathrm{~cm}$ in length. $\mathrm{He}$ further subdivided the smaller beads into a group with trunk-like heads with stalk-like, protruding eyes, and a group with rounder heads and eyes likely created by secondary heat treatment of the beads. ${ }^{27}$ The eyes and nostrils of the heat treated examples are more clearly fused to the head and display a gradually sloping join (see Fig. 1) while the protruding examples rise from the head much more abruptly (e.g., the solid blue beads in Fig. 4). However, in practice, it is often difficult to distinguish between the heat-treated examples with rounded heads and eyes and those with trunk-like heads and protruding eyes. I propose that for typological assessments it is also useful to differentiate singlecolour beads from multicoloured beads, and for the multicoloured beads, to differentiate between those with eyes and/or nostrils made from two, three, or four layers of glass prior to assessing the presence or absence of heat treatment. The proposed modification to Egg's 2010 typology yields a more detailed typology that can be utilized even with fragmentary beads or beads where it is not possible to assess the presence or absence of heat treatment (see App. 1).

Type 1: Large beads (2.0 $\mathrm{cm}$ or larger)

Type 2: Single-colour beads (1.5 $\mathrm{cm}$ on average)

Type 3: Multicoloured beads:

Variant 3a: Two-layer eyes and nostrils:

$-3 a . i$. Protruding eyes and nostrils (not heat treated)

- 3a.ii. Flattened or rounded eyes and nostrils (heat treated)

Variant 3b: Three-layer eyes

- 3b.i. Protruding eyes \& nostrils (not heat treated)

- 3b.ii. Flattened or rounded eyes and nostrils (heat treated)

Variant 3c: Four-layer eyes

- 3c.i. Protruding eyes \& nostrils (not heat treated)

- 3c.ii. Flattened or rounded eyes and nostrils (heat treated)

Beads of Type 1 are marked by their variability in addition to their large size. The Type 1 beads currently identified have two- or four-layer eyes and nostrils, two have ears, ${ }^{28}$ and one lacks nostrils entirely. ${ }^{29}$ Currently, this type has only been identified at sites in Novo mesto. Type 2 beads appear at Stična, Vinkov vrh, and at Kapiteljska njiva in Novo mesto in small numbers. Thirty-five

27 Egg 2010, 529-531.

28 Novo mesto - Kandija IV/3 and Kapiteljska njiva Grave III/49, Dolenjski muzej P 270 and P 2316.

${ }^{29}$ Kapiteljska njiva XIV/41, Dolenjski muzej P 4557.

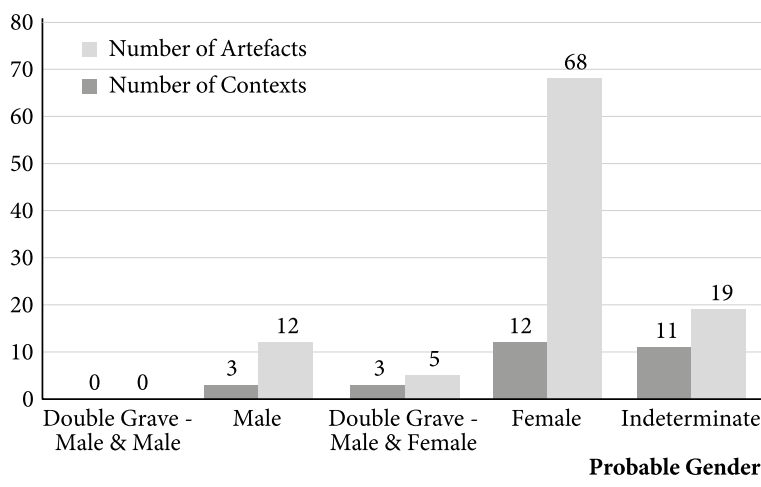

Fig. 3: Grave contexts with ram's head beads divided according to probable gender. Solely probable gender is indicated since skeletal remains rarely preserve in this region and osteological analysis has not been possible, gender attribution is based on grave goods. (See Fn. 25 for more details).

Sl. 3: Grobne celote z jagodami v obliki ovnove glavice po pripadnosti domnevnemu spolu. Opredelitev spola temelji na grobnih pridatkih, ker človeški kostni ostanki večinoma niso ohranjeni, zato osteološka analiza ni mogoča. (Za več podrobnosti gl. op. 13).

beads of this type were recovered from Valična vas, though unfortunately their within-site provenience is unknown. It is unclear if there are meaningful chronological or spatial distinctions in Types $3 \mathrm{a}$, $3 b$, and $3 c$, or whether the layering of the eyes and nostrils was a purely stylistic choice. However, it is notable that there is a clear correlation between increasing frequency of heat treatment with threeto four-layer eyes and nostrils (Types $3 \mathrm{~b}$ and $3 \mathrm{c}$ ). Currently there are only two beads of Type $3 \mathrm{~b} . \mathrm{i}^{30}$ and one of Type $3 \mathrm{c} . \mathrm{i}^{31}$ while there are over 25 heat-treated examples of Type $3 b$.ii or $3 c$.ii.

There is a clear concentration of bead types at sites in Novo mesto. Kapiteljska njiva contains every bead type except Type 3c.i, supporting the proposal that this area was a centre for the production of ram's head beads. In fact, all these bead types appear in Tumulus V and VI at Kapiteljska njiva: Tumulus $\mathrm{V}$ contains three graves with 19 ram's head beads and Tumulus VI contains three graves with 11 beads. An outlier is the high number of Type 2 beads at Valična vas, which could indicate that this type of bead was produced elsewhere or circulated through different distribution networks

30 Three-layered eyes and nostrils (not heat treated) Kapiteljska njiva V/40, Dolenjski muzej P2503.

31 Four-layered eyes and nostrils (not heat treated): Vinica - Stražni dol Grave 122, Peabody Museum of Archaeology and Ethnology PM 40-77-40/10977 [https:// pmem.unix.fas.harvard.edu:8443/peabody/]. 


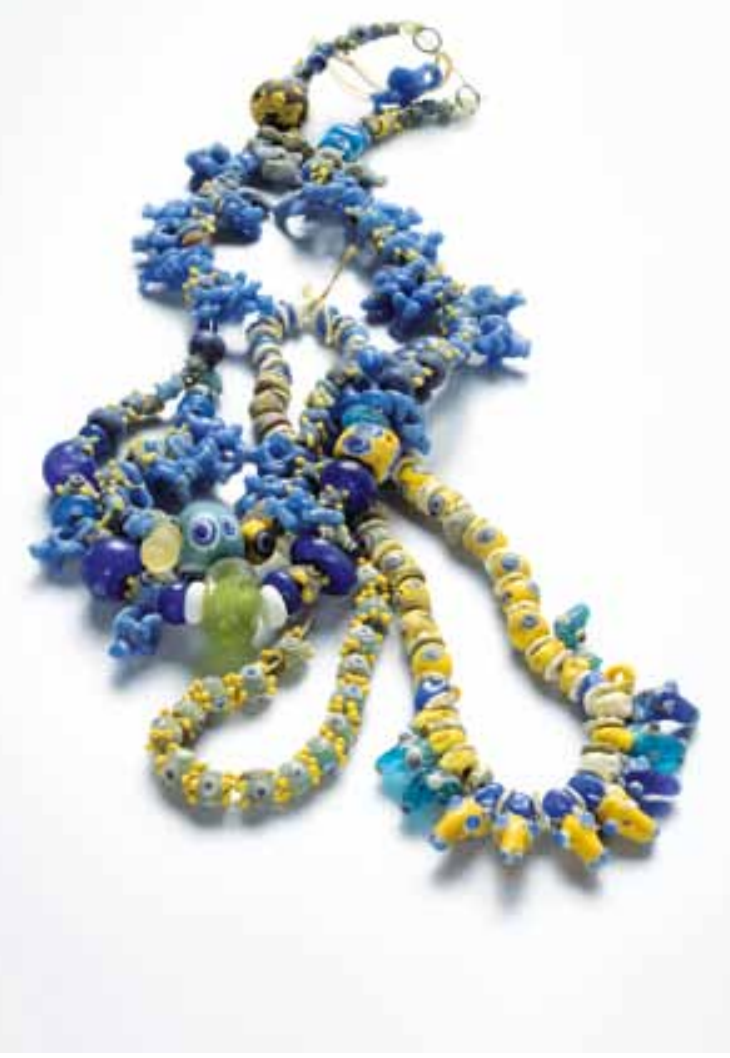

Fig. 4: Necklaces with ram's head beads from Vintarjevec Grave 2 (bottom) and an unknown provenience at Valična vas (top). The necklace from Vintarjevec is composed of glass, amber, and bone beads. Only 10 of the original 14 ram's head beads are intact, the other four are represented by solely their loops. The beads are made of yellow, white, aqua, blue, and dark blue glass. The necklace from Valična vas is made of amber and glass beads. Thirty-five of the ram's head beads are made entirely of opaque, light blue glass, while one bead is made of white, dark blue, and brown glass. It is important to note that the beads from Valična vas were strung together for curation, these beads are unprovenienced and it is unlikely they were all originally part of the same necklace.

Sl. 4: Ogrlici z jagodami v obliki ovnove glavice iz groba 2 v Vintarjevcu (spodaj) in neznanega konteksta iz Valične vasi (zgoraj). Ogrlico iz Vintarjevca sestavljajo steklene, jantarne in koščene jagode. Od prvotnih 14 jagod v obliki ovnove glavice se jih je v celoti ohranilo 10, od preostalih štirih pa le zanke. Izdelane so iz rumenega, belega, modrozelenega, modrega in temnomodrega stekla. Ogrlico iz Valične vasi sestavljajo jantarne in steklene jagode, med njimi je 34 enobarvnih v obliki ovnove glavice iz prosojnega in svetlomodrega stekla, ter ena večbarvna iz belega, temnomodrega in rjavega stekla. Jagode so bile nanizane za namen hrambe, medtem ko njihov izvorni kontekst ni znan, zato prvotna pripadnost isti ogrlici ni zanesljiva.

(After / Po Laharnar, Turk 2018, 131 Fig. 151) than the other types of ram's head beads, however at this point there is not enough data to determine which is more plausible.

Interestingly, beads occurring in groups of two or more from single grave contexts are typologically heterogeneous in all but three cases. Novo mesto - Kapiteljska njiva Grave VI/40 has a matched set of two beads of Type $3 \mathrm{~b}$.i with white heads and blue eyes and loops, Vintarjevec Grave 2 has 14 matching beads of Type $3 \mathrm{a}$ in blue, aqua, and yellow with white details, while Vinica - Stražni dol Grave 237 has three matching beads of type 3a.ii made of dark blue, white, and aqua glass. The ten other grave contexts containing multiple beads are more heterogeneous with two or more types of ram's head beads in each grave. These more varied collections of beads are in many cases composed of multiple pairs or small sets of matching beads. For example, Grave 13/97 from Magdalenska gora - Preloge contains 11 glass ram's head beads. Three of these beads are a matched set of Type 3a.ii with green heads, blue and white two-layer eyes and noses, with yellow, white, and brown twisted horns, and a blue loop. These beads are nearly the exact same size ${ }^{32}$ and were clearly made as a matching set. In the same grave there is an extremely similar blue bead also of Type 3a.ii, though with a blue head and yellow loop, as well as two damaged beads that are also Type 3a.ii but with yellow heads. In addition, there are also three beads of Type $3 \mathrm{~b}$.ii and one of type 3c.ii. This pattern of heterogeneous groups of beads containing at least one or two smaller matched sets characterizes most graves with multiple beads. At this time, it is unclear whether this relates to a preference for a variety of beads, patterns of bead production or circulation, or how they were obtained (e.g., they were accumulated over time and sets became larger as women aged), though this is a pattern worthy of further exploration.

\section{THE IMPORTANCE OF SHEEP}

Apart from the ubiquitous ram's head beads, it is remarkable how rare depictions of sheep are in Dolenjska. A pair of crossbow fibulae with the foot terminal in the shape of ram's heads were identified in Grave 2/b from Preloge at Magda-

32 They are all within $1 \mathrm{~mm}$ of each other in measures of length, size, and width. See Frie 2017, 526 for images and dimensions. 
lenska gora and a single fibula was identified in Grave X/48 at the same site. ${ }^{33}$ There are only two situlae depicting sheep, one from Grave 1881/1 at Vače - Reber ${ }^{34}$ and another from Grave III/12 at Kapiteljska njiva in Novo mesto. ${ }^{35}$ There is also an unusual rhyton from Grave IV/47 at Stična. ${ }^{36}$ This was certainly an import, likely from the eastern Adriatic, though there are Greek and Apulian examples known as well. ${ }^{37}$

The relatively limited corpus of sheep imagery beyond ram's head beads has made interpretations their symbolic significance difficult. Rams in particular do seem to have a ritual function in the form of animal sacrifice. The situla from Grave III/12 at Novo mesto - Kapiteljska njiva depicts a sheep wearing a lead or harness being led by a man, while the Vače situla has a similar scene though the ram is following a man with an axe. The sheep on the Vače situla is identified as a ram due to the clearly depicted testes, while the Novo mesto situla is too fragmentary to differentiate between ram and wether (castrated male) since wethers are also horned, though their horns are less robust than those of rams. Another line of evidence indicating sheep were funerary sacrifices is provided by graves, some of which contained sheep/goat remains. ${ }^{38}$

It has been proposed that rams were symbols of fertility in the south-eastern alpine Iron Age. Hrvoje Potrebica has argued that rams were symbolic of fertility and fire based on the presence of glass and amber ram's head beads in female graves as well as finds of askoi and other vessels elaborated with sheep from Croatia. ${ }^{39}$ However, he does not elucidate why rams are thought to be symbolic of fertility beyond the association of ram's head beads with women. The link between fertility symbolism and women should be demonstrated rather than assumed, or we risk flattening the role of past women to nothing more than child bearers. ${ }^{40}$ And if it is the case that rams are associated with

\footnotetext{
${ }^{33}$ Magdalenska gora - Preloge Grave 2/b: Tecco Hvala, Dular, Kocuvan 2004, 124-125, Pl. 9. Magdalenska gora - Preloge Grave X/48: Hencken 1978, 74, 260, Fig. 298.

${ }^{34}$ Laharnar, Turk 2018, 100-101, Fig. 111; Frie 2020; Murgelj 2020.

${ }^{35}$ Križ 1997b, 24-28, Appendix 3.

36 Wells 1981, 66, 184, Fig. 101.

37 Hoffmann 1966; Wells 1981, 66.

38 Frie 2020

39 Potrebica 2012, 13-14.

${ }^{40}$ Conkey, Spector 1984; Wylie 2002, 185-199; Brum-
} fiel 2006. female fertility, the question still remains - why sheep, and more particularly, why rams?

Mitja Guštin and Pasko Kuzman also support the idea that fertility plays a role in ram imagery, though they interpret ram imagery as associated with male fertility and the fertility of the flock. In addition, they connect much of the widespread ram imagery of southern Europe with the myth of the golden fleece and the Argonauts. ${ }^{41}$

It should be noted that securely identifying all these images as rams is difficult. In the case of intact ram's head beads, the large, forward-curling horns do likely indicate rams rather than wethers or ewes. In the larger dataset, imagery depicting sheep was identified on the basis of their unique horn morphology - the horns sweep backward before curling forward around the ears, which is most pronounced in rams. The horns of ewes sweep backward in a scimitar shape, and do not curl forward or become large in the way of rams' horns. Wethers show more variability; they were likely horned as well though their horns would have grown less quickly and would not have become as robust as the horns of intact rams. In this period both rams and ewes were usually horned throughout southeastern Europe, though unusually the remains of a hornless (polled) sheep were identified at the hillfort at Cvinger above Vir pri Stični, indicating that some variation existed. ${ }^{42}$ So while these beads are uniformly called ram's head beads and many sheep in iconography are referred to as rams, identifying the sex of the animal and differentiating between a ram and a wether is difficult when the horns have not preserved, which is often the case with ram's head beads.

The ubiquity of ram's head beads matches the significance of sheep in local subsistence - sheep are the second or third most common animal ${ }^{43}$ identified in faunal remains at Dolenjska Hallstatt hillforts. ${ }^{44}$ The high quantity of sheep bones may indicate a number of things since sheep are significant for the production of meat, milk, hides, and wool. Cvinger hillfort above Vir pri Stični

${ }^{41}$ M. Guštin and P. Kuzman, The Chrysomallos, symbol of fertility in the antiquity (in preparation).

42 Bökönyi 1974; 1994, 197.

43 We cannot determine if sheep are second most common and goats are third or vice versa, since counts of sheep and goat remains are aggregated because they usually cannot be distinguished in archaeozoological analysis (Boessneck 1969; Prummel, Frisch 1986; Zeder, Lapham 2010; Salvagno, Albarella 2017).

44 Bartosiewicz 1991; 1996; Bökönyi 1994, 196. 
has produced the most detailed data concerning sheep remains. Though rams, ewes, and wethers are all attested, in most cases it was not possible to determine the sex of the remains, which would otherwise provide insight into herd demographics and the importance of milking and wool production as compared to exploitation for meat. ${ }^{45}$ Age profiles are available, though only for the mixed category of sheep/goat. However, these provide some insight into culling patterns and indicate that while sheep were exploited for meat this was likely not their primary purpose, indicated by the fact that most animals were kept until they were adults or even mature animals. ${ }^{46}$ The ideal age for slaughtering sheep for meat is approximately two years, while ewes may produce milk until they are around seven, and wool is consistently available from sheep throughout their lives. ${ }^{47}$ The age profiles from Cvinger above Vir pri Stični support the possibility that sheep were kept for milk and wool and were not slaughtered for meat until those secondary products had been utilized for several years. ${ }^{48}$

Maintaining flocks of sheep would have necessitated significant care and daily interaction by Dolenjska Hallstatt people. Lambs are born in the spring, and productive milking periods would have followed, necessitating close proximity of human caregivers for frequent milking of ewes and care for lambs. ${ }^{49}$ Spring was also a period when wool was plucked. ${ }^{50}$ Fall was generally a time for slaughter and preparing meat for winter storage. Fodder also needed to be gathered and stored to maintain the remaining flock through winter. ${ }^{51}$ Throughout the year sheep were often moved to fallow fields to provide fresh grazing material and so that their manure could be used as fertilizer. ${ }^{52}$ Their movements would have required the services of shepherds to ensure their safety when away from pens. Sheep are social animals and tend to

\footnotetext{
45 Bökönyi 1994, 197.

46 Ib., 202, Table 10.

47 Green 1992, 30, 36; Greenfield, Arnold 2008, 838; Calder 2011, 19-21.

48 Green 1992, 11; Bökönyi 1994, 202.

49 Calder 2011, 20.

50 Shears did not develop until the Late Iron Age, possibly in concert with non-shedding fleece (Grömer 2016, 68, 275).

51 Reynolds 1987, 50-60; Green 1992, 16, 30.

52 Reynolds 1987, 40-44.
}

bond with their dominant shepherds, both human and animal. ${ }^{53}$

Daily care and interaction provided a distinctly social aspect to human-sheep relationships, and their economic importance cannot be denied. They provided essential primary and secondary resources, allowed increased self-sufficiency of households, and can be considered a form of mobile wealth. ${ }^{54}$ Sheep may have been more widely available than cattle based on the smaller expense of both obtaining and maintaining sheep. They produce useable resources throughout their lives (milk, wool, manure), and when they are culled the meat yield is smaller and more suitable for household consumption than the meat yield from cattle. ${ }^{55}$ They were clearly important parts of Dolenjska Hallstatt households, and this familiarity and resource significance translated to iconographic significance. However, other animals were also economically significant including cattle, pigs, and goats, ${ }^{56}$ though they appear much less in local imagery. Delving into what sets sheep apart can provide key insight into their importance in local iconography.

One essential quality that differentiates sheep from other domesticates is their importance for producing wool used in textiles. Unfortunately, due to the nature of the archaeological record, perishable materials such as textiles may not preserve or may be overlooked in archaeological interpretations. ${ }^{57} \mathrm{It}$ is proposed that ram's head beads were particularly important to women because they demonstrated a woman's link to the textile economy, an important activity both economically and in the definition of female roles.

\section{WOOL AND WOMEN}

The ubiquity of spindle whorls in settlement and grave contexts, as well as loom weights and needles to a more limited extent, highlights the importance of textile production to local economies. In addition, recent work on pre-Roman textiles has indicated that Early Iron Age peoples were familiar with complex patterns, tablet weaving,

\footnotetext{
53 Clutton-Brock 1999, 73; Mlekuž 2013, 152.

54 Mlekuž 2013, 155.

55 Calder 2011, 19.

56 Bartosiewicz 1991; 1996; 1999; Bökönyi 1994.

57 Gillis, Nosch 2007.
} 
and dyeing technologies. ${ }^{58}$ The Early Iron Age was a period of highly refined textile production, to the extent that attached specialist production has been proposed. In the Mediterranean, several types of specialized production are known: Linear $B$ records indicate textile workshops as well as elite household production served Mycenaean palace centres, elite women in Archaic Greece wove highquality textiles with the help of servants, while imagery and textile tools in graves indicate that textile production was an important aspect of elite female identity in Etruria. ${ }^{59}$ By the Late Bronze Age it was possible to spin wool into thread of just $0.1 \mathrm{~mm}$ thickness, and the ubiquitous light spindle whorls of later Hallstatt period female graves are ideally suited to weaving fine threads of this type. ${ }^{60}$

While much of the current textile evidence comes from the Mediterranean ${ }^{61}$ or the salt mines of Hallstatt and Dürrnberg, ${ }^{62}$ finds from Slovenia demonstrate that high-quality production was prevalent in this region as well. New analysis of a preserved textile fragment from Grave 1/6 at Pleška hosta near Molnik indicates that it was a zigzag twill of unusual fineness. The thread itself measures $0.2 \mathrm{~mm}$, and the thread count is between 28 and 32 threads per $\mathrm{cm}$, which makes it one of the finest textiles recovered from the Eastern Hallstatt area. ${ }^{63}$ Other textiles from Slovenia have thread counts between 20 and 22 threads per cm. ${ }^{64}$ The apparent high quality of local textile production, as well as the frequent finds of spinning and weaving tools in settlements and graves indicates that cloth production was an important local craft, and textiles may have been an important trade item circulating in elite networks. ${ }^{65}$

The spinning and weaving of wool was apparently a female activity, based on the frequent finds of spindle whorls and loom weights in female graves,

58 Bender Jørgensen 2005; Bichler et al. 2005; Gleba 2007; 2009; Gleba, Mannering 2012; Rast-Eicher, Bender Jørgensen 2013; Grömer 2016; Grömer, Saliari 2018.

59 Gleba 2009; Grömer 2016, 252-253; Halstead, Isaakidou 2017.

${ }^{60}$ Grömer 2016, 87, 91.

61 E.g., Gleba 2008; 2014 b.

62 E.g., Ryder 1990; Bichler et al. 2005; Stöllner 2005; Grömer, Stöllner 2011; Grömer 2012; Grömer et al. 2013; Grömer, Saliari 2018.

63 Grömer, Tolar, Kostajnšek 2017.

64 Bender Jørgensen 2005, cat. nos. 98, 114; Grömer, Tolar, Kostajnšek 2017, 212-214; Grömer et al. 2018, 458-459.

65 Nash Briggs 2003; Grömer 2017. as well as iconography from the surrounding regions. ${ }^{66}$ Though there are currently no depictions of female textile production from Dolenjska, the throne from Verucchio Tomb 89 depicts spinning and weaving, ${ }^{67}$ while the tintinnabulum from Tomba degli Ori at Bologna is decorated in the situla art style with scenes of elite women carding wool, spinning it into thread, and weaving on an elaborate two-story loom (Fig. 5). ${ }^{68}$ Women spinning wool and weaving on a loom are also depicted on a ceramic vessel from Tumulus 27 at Sopron -Várhely in Hungary (Fig. 6) ${ }^{69}$ In this scene the women are accompanied by an individual who may be either holding a small weaving frame $\mathrm{e}^{70}$ or playing the lyre. ${ }^{71}$ The latter interpretation supports proposals that women, music, and textiles were closely linked through the use of repetition in songs and poetry to encode complex weave patterns. ${ }^{72}$ This would have made weaving an important social as well as economic activity for local women, perhaps linked to ritual practice through story and song. ${ }^{73}$ While depictions of women are not very common in south-eastern Europe, it is not incidental that several of them involve the production of textiles. ${ }^{74}$ Textile production was not simply women's work; it was an activity intimately tied to expressions of prestige, elite gift giving and diplomacy, and may have been a ritually significant activity with rich symbolic connotations. ${ }^{75}$

These varied strands of evidence demonstrate an emerging pattern linking women, textiles, and sheep. The association between women and textile production is clear while the data from ram's head beads also shows an association with women. Twelve female graves were identified containing 68 ram's head beads, and if we consider the doublegraves containing a woman, we can add another three graves and five beads. There are three male

66 Bonfante 1985; Eibner 1986; 2005; Barber 1991; 1994; Teržan 1996; 2004; Primas 2007; Gleba 2009; Huth, Kondziella 2017.

67 Gleba 2008, 28-29; Gleba 2009, 69-70, Fig. 1.

68 Bonfante 1985, 280-281, 283; Bonfante 2011, 207, Fig. 2.

69 Teržan 2004, 223, Fig. 2; Gleirscher 2009, 217, Fig.

8; Bonfante 2011, 206, Fig. 1 .

70 Teržan 1996, 526, fn. 52.

71 Eibner 1986.

72 Bonfante 1985, 283, Fig. 6; Tuck 2006.

73 Eibner 2005.

74 Rebay-Salisbury 2016, 110-136, 223-225, 250.

${ }^{75}$ E.g., Eibner 1986; 2005; Teržan 1996; Rebay-Salisbury 2016, 223-225. 

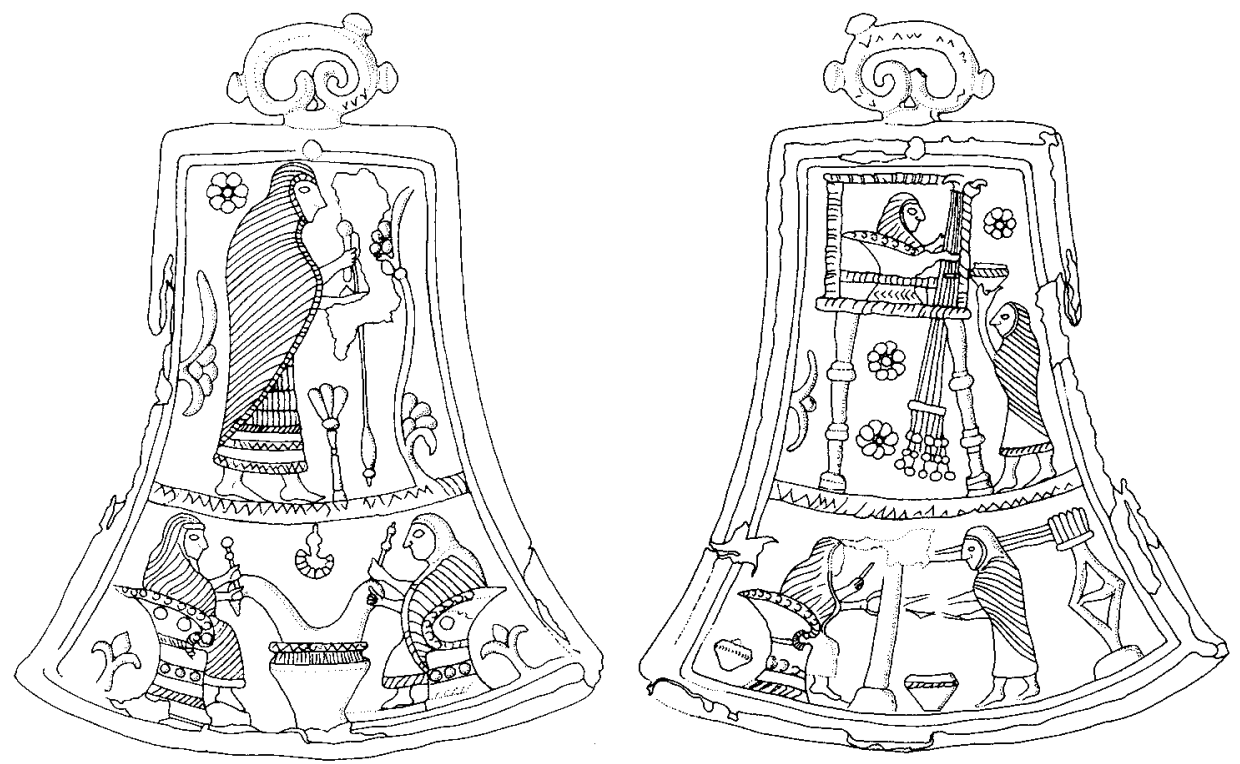

Fig. 5: Bronze tintinnabulum from Bologna - Tomba degli Ori.

Sl. 5: Bronasti zvonec iz Bologne - Tomba degli Ori. (After / Po Turk 2005, 27 Fig. 34)

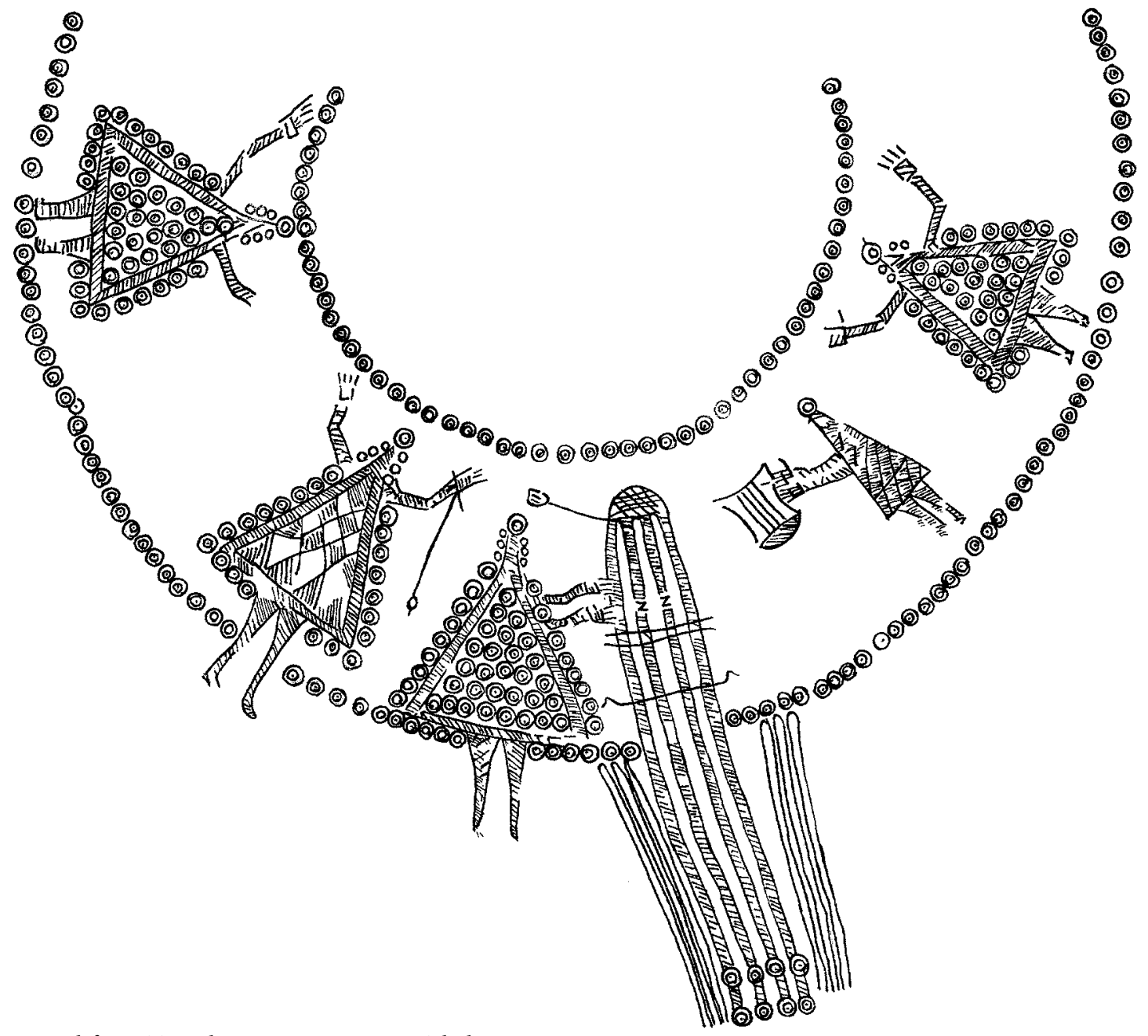

Fig. 6: Vessel from Tumulus 27 at Sopron - Várhely.

Sl. 6: Lončena posoda iz gomile 27 v Sopronu - Várhely.

(After / Po Eibner-Persey 1980, Pl. 17, redrawn by author / preris: avtorica) 
graves containing twelve ram's head beads - 11 glass and one bronze bead. However, these graves account for just $12 \%$ of the ram's head beads recovered from graves, while female graves account for $65 \%$. The ceramic rhyton from grave IV $/ 47$ at Stična is associated with a female individual, ${ }^{76}$ while sheep/goat remains ${ }^{77}$ were identified in Grave 4 from Grofove njive near Drnovo and in two graves from Preloge near Magdalenska gora. Grave 4 from Grofove njive contained the hind leg of a caprovid along with ceramic vessels, bronze fibulae, small rings, and a belt plate, and an iron arrowhead indicating a possible male burial. ${ }^{78}$ At Magdalenska gora, Grave $13 / 163^{79}$ belonged to a probable female while the gender of the deceased in Grave VII/29 $9^{80}$ could not be determined. Grave $13 / 163$ also contained a bone needle and spindle whorls, providing support for the association between sheep and textile production. An association between women and sheep/goat remains characterizes some contemporary cultures, Nils Müller-Scheeßel and Peter Trebsche noted that Hallstatt women's graves in Central Europe also contained deposits of mutton or goat, while men were buried with cuts of pork. ${ }^{81}$

\section{RAM'S HEAD BEADS AND TEXTILE EQUIPMENT}

The graves in the study with spindle whorls and loom weights were examined further to assess the potential association between ram's head beads and textile production (App. 2). A total of nine graves containing ram's head beads also contained textile equipment $(31 \%)$ - eight graves contained spindle whorls, while an additional grave contained a spindle whorl and two loom weights. To determine whether a $31 \%$ association is meaningful, it is necessary to have a better sense of how common it was to deposit textile equipment in graves in this region. To this end data from the published excavations at Novo mesto - Kapiteljska njiva were

76 Wells 1981, 66, 184, Fig. 101.

77 This excludes remains positively identified as goats, and only includes the indeterminate identification of sheep/goat.

78 Pavlovič 2014, 493-4.

79 Tecco Hvala, Dular, Kocuvan 2004, 162, Pls. 123-124; Tecco Hvala 2012, 31, 90, Fig. 36.

${ }^{80}$ Hencken 1978, 56; Tecco Hvala 2012, 30, 90, Fig. 36.

81 Müller-Scheeßel, Trebsche 2007. assessed, ${ }^{82}$ since this is a large, well-excavated site, the centre of ram's head bead deposition, and a probable centre of production.

Nearly a quarter of burials in the published tumuli at Novo mesto - Kapiteljska njiva contain textile equipment (Fig. 7). This demonstrates that the $31 \%$ rate of association between ram's head beads and textile equipment is slightly higher than one would expect if there were no connection between these two items. Supplementary support comes from the other graves where sheep imagery or faunal remains and textile equipment co-occur: Grave IV/47 from Stična contains the sheep rhyton as well as a spindle whorl, ${ }^{83}$ and as previously noted, Grave 13/163 from Magdalenska gora - Preloge contains sheep/goat remains along with a spindle whorls and needle. ${ }^{84}$ In addition, the situla depicting a sheep being led to sacrifice was from Grave 1881/1 at Vače - Reber, which contained artefacts traditionally associated with both males and females including a spindle whorl. ${ }^{85}$ One of only two instances of a ram's head bead in a settlement context comes from Trench 1, Layer 2 at Špičasti hrib, which contained a ram's head bead as well as spindle whorls. ${ }^{86}$ It is also plausible that if there was a symbolic connection between ram's head beads and textile production, ram's head beads could have been deposited in lieu of textile tools in graves. In this case, a relatively low rate of co-occurrence of textile equipment and ram's head beads would be expected, despite the strong symbolic associations connecting these items.

While these examples do not definitively demonstrate the association between sheep imagery and textile production, they are highly suggestive. Ram's head beads may have served a similar function to spindle whorls in burial deposition - that is, both textile equipment and ram's head beads indexed wool and textiles, ${ }^{87}$ and so were appropriate grave goods to indicate a woman's link to the textile economy. If this is the case, it may have made the deposition of both unnecessary

\footnotetext{
82 Križ 1997b; 2000; 2013.
}

83 Wells 1981, 66, 184, Fig. 101. Though it should be noted that this grave is part of the Mecklenburg Collection, and graves from this collection should be treated with caution due to their early excavation and complex history - see Božič 2009; Tecco Hvala 2012, 28.

84 Tecco Hvala, Dular, Kocuvan 2004, 162, Pls. 123-124.

85 Božič 2015; Dular 2016, 76-77.

86 Dular, Pavlin, Tecco Hvala 2003, 199-200.

87 Sensu Peirce 2012: sheep imagery points to and is logically linked to wool and textiles. 


\begin{tabular}{|c|c|c|c|}
\hline Tumulus & Total Number of Graves & $\begin{array}{c}\text { Number of Graves with } \\
\text { Textile Equipment }\end{array}$ & $\begin{array}{c}\text { Number of Graves with } \\
\text { Ram's Head Beads }\end{array}$ \\
\hline I & 81 & $18(22 \%)$ & 0 \\
\hline II & 36 & $8(22 \%)$ & 1 \\
\hline III & 56 & $16(29 \%)$ & 3 \\
\hline IV & 3 & $2(67 \%)$ & 1 \\
\hline V & 74 & $16(22 \%)$ & 0 \\
\hline XIV & 55 & $15(27 \%)$ & 7 \\
\hline
\end{tabular}

Fig. 7: Frequency of textile equipment in published tumuli from Novo mesto - Kapiteljska njiva.

Sl. 7: Pogostnost najdb tekstilnih pripomočkov v objavljenih gomilah iz Novega mesta - Kapiteljska njiva.

in certain cases. The logical connection between ram's head beads, sheep and wool, and a thriving textile economy is worthy of consideration, and may provide the missing piece needed to understand the local significance of ram's head beads deposited in female graves.

However, this does not account for the twelve ram's head beads in three male graves, two from Kapiteljska njiva in Novo mesto ${ }^{88}$ and one from Grave VII/1 at Brezje pri Trebelnem. ${ }^{89}$ The latter example from Brezje may not have had the same symbolic connotations as the glass examples, since the bead itself is a reworked fibula and the grave inventory is unusual. However, the two male graves from Kapiteljska njiva in Novo mesto contain glass ram's head beads like those found in female graves, and they indicate that these items were not restricted to females. It may be that these men were also textile producers, that these beads were a gift from a female mourner, or that these men also had a connection to sheep or their products that was important to materialize in death. It is interesting that these graves are in Novo mesto, which is believed to be the centre for production of ram's head beads. It is also possible that these men were associated with production of these beads $s^{90}$ or otherwise had unusual access to these primarily female items.

The mortality profiles from Cvinger at Stična point to the importance of keeping sheep for wool

88 Grave VII/28: Križ, Stipančić, Škedelj Petrič 2009, 257; Grave XIV/41: Križ 2013, 126, 128, 198-199, Pls. 52-53.

${ }^{89}$ Kromer 1959, 22-23, Pls. 20; 21; Dular, Križ 1990, 538.

90 Though it should be noted that there is no evidence that the production of glass was a gendered activity.
- a period of many years in which local people would have developed relationships with their animals. New evidence also indicates that there was likely a robust household industry ${ }^{91}$ of textile production in this region, one that seems to have been dominated by women based on grave finds and iconography. It is plausible that the importance of sheep iconography was anchored in these local relationships, where sheep and their products facilitated the distinction of local women through the production of textiles for their communities and for trade. Depositing ram's head beads in graves may have represented a particular aspect of female identity - analogous to the deposition of textile equipment, sheep iconography may have served to materialize the important relationship between women, sheep, and textiles.

\section{THE SOCIAL CONTEXT OF RAM'S HEAD BEADS}

If ram's head beads were used to signal participation in textile manufacture, they were doing so

91 Currently a household industry is more plausible than workshops since there is no evidence in this region for the kinds of Early Iron Age textile workshops known from Etruria (Gleba 2007; 2009). This could be due to relatively limited settlement excavations that have not yet exposed evidence for highly centralized or workshopstyle production. However, the continuing importance of textile tools in grave contexts indicates that even if there was nascent workshop production in this area, a strong association between individual women and spinning and weaving tools remained, implying the continued importance of textile production to female identity. 
through the medium of personal display, specifically through adornment. Personal ornaments are quite common in the Dolenjska Hallstatt area, and also dominate the dataset for artefacts elaborated with animal imagery. ${ }^{92}$ It is clear that animal imagery played an important role in signalling various aspects of identity and affiliation through the medium of bodily display. ${ }^{93}$ Personal ornaments are primarily found in female graves, and the majority of zoomorphic ornaments are ram's head beads. ${ }^{94}$ Zoomorphic beads are not singular items; rather, they appear in groups or with other non-zoomorphic glass and amber beads (see App. 2 ) indicating that these were parts of larger sets of beaded jewellery that were likely meant for display. This does not preclude the possibility that these beads had an apotropaic value as suggested for other parts of Iron Age Europe; ${ }^{95}$ however it does not seem that a protective function was their sole purpose. Ostentatious display may have been an important function of these items - complex glass production, especially using multiple colours, was a relatively new technology and would have presented a colourful novelty, ${ }^{96}$ while the foreign origin of glass may have signalled wealth and access to long-distance trade networks. ${ }^{97}$

The amber ram's head beads would have also made a statement. Amber represented access to distant lands and had its own evocative properties such as its warmth against the skin, translucence, conduction of static electricity, and the ability to float, all of which set it apart from other materials. ${ }^{98}$ Ram's head beads in general are strongly associated with other types of amber artefacts in the study region. The 29 intact graves with ram's head beads also contained amber in 22 instances (76\%, see App. 2). If possession of ram's head beads was related to participation in an elite textile economy, this may have allowed these women access to imported items such as amber, either through direct trade for textiles, or possibly through the networks of gift-giving in which textiles and other luxury items were circulating.

92 Frie 2017, 187-212.

93 Joyce 2005; Castor 2016; Martin, Weetch 2017.

94 Frie 2017, 195-198.

95 Pauli 1975, 131; Bakarić, Križ, Šoufek 2006, 67; Rebay-Salisbury 2016, 181; Hladíková 2018.

96 Križ, Turk 2003; Križ, Guštin 2015.

97 Helms 1993; Šmit, Laharnar, Turk 2020.

98 Helms 1993; Grimaldi 1996, 144; Bakarić, Križ, Šoufek 2006, 13-21; Causey 2011, 37-41.
It is also quite possible that the display of ram's head beads directly or indirectly signified ties to particular sites. If the production of glass ram's head beads was centred in Novo mesto, the distribution of ram's head beads outside Novo mesto may signify the movement of women between sites, perhaps through exogamous marriage patterns. ${ }^{99}$ Tumuli $\mathrm{V}$ and VI at Kapiteljska njiva have a significant concentration of ram's head beads, and if tumuli are centred on families or lineages as has been proposed, ${ }^{100}$ these two tumuli may represent the centre of a widespread familial network.

The distribution of ram's head beads suggests that the communities at Stična, Magdalenska gora, Valična vas, and Vinkov vrh had particularly strong ties with Novo mesto (see Fig. 2). The connection between Stična, Novo mesto, and Magdalenska gora is logical, as they were three of the largest Early Iron Age sites in the region and were important trade centres. In addition, Janez Dular and Sneža Tecco Hvala's least-cost path analysis of routes between Dolenjska Hallstatt settlements demonstrated that the primary north-south route in the region ran from Magdalenska gora to Stična and on to Novo mesto and connected smaller sites between them. ${ }^{101}$ Additional support for these connections comes from the position of these sites on the western edge of the Dolenjska region. Sneža Tecco Hvala and Brina Škvor Jernejčič have suggested that these sites shared a military nature, evidenced by the significance of weapon graves dating to the Certosa Fibulae and Negova Helmets phases. They suggest that these sites were linked as a line of defence along the western edge of Dolenjska along the Krka River and Savska ravan plain, and may have even housed garrisons. ${ }^{102}$ If this is the case, these sites were linked not only by regional routes and geography, but also by a shared defensive role. ${ }^{103}$ This may have fostered close connections between these sites, increasing exchange of items such as ram's head beads, either as trade items or traveling with the women to whom they belonged.

Based on the available information, ram's head beads conveyed complex meanings in Dolenjska

99 See Arnold 2005 and Oelze et al. 2012 for discussions of Iron Age female mobility in Central Europe.

100 Gabrovec 1966; 1987; Teržan 2008; Tecco Hvala 2012.

101 Dular, Tecco Hvala 2007, 191-196, 220-222.

102 Tecco Hvala 2012, 142-143, 381; Tecco Hvala, Škvor Jernejčič 2017, 169-170.

103 I must thank Boštjan Laharnar from National Museum of Slovenia for drawing my attention to the connections between these sites. 
Hallstatt societies. They indicated economic aspects of women's identities, including participation in long-distance trade networks via production. ${ }^{104}$ Elite or diplomatic gift exchange has long been considered an essential aspect of Hallstatt social relations, both for establishing long-distance social relationships but also for displays of wealth and power. While elaborate imports have often been the focus of studies of exchange, it is worth considering that fine textiles may have also played role in these long-distance networks. These systems were not only focused on imports and did not confer prestige solely on the men who are implicitly assumed to control these systems. ${ }^{105}$ Exports also played an essential role and may have conferred status and economic power on the women who produced fine textiles. This brings to light an under-considered aspect of Early Iron Age society - the role of women in the broader socioeconomic networks in which textiles circulated via long-distance exchange and gift giving. Scenes of women carding wool, spinning thread, and weaving together are not simply domestic scenes in Iron Age imagery, they likely demonstrate the central role of women in elite networks. Social capital was not the sole purview of elite men, though we often focus on the significance of men as warriors and hosts. ${ }^{106}$ We should consider the possibility that women also played a central role in elite networks, and brought luxury goods and prestige to themselves and their communities through the work of their hands. ${ }^{107}$ Ram's head beads may have materialized the socioeconomic power of certain women, vividly displayed as part of elaborate, colourful necklaces that women wore throughout their lives and that were significant enough to go with them into the grave.

\footnotetext{
104 Nash Briggs 2003; Gleba 2009; 2014a; Bonfante 2011; Grömer 2017.

105 Frankenstein, Rowlands 1978; Gosden 1985; Dietler 1990; Helms 1993; Arafat, Morgan 1994; Babić 2002; Tacla 2008.

106 Frie 2018a; 2018b.

107 Bonfante 1985; Eibner 1986; 2005; Teržan 1996; 2004; Gleba 2009; 2014a.
}

\section{CONCLUSION}

In sum, sheep imagery was likely polyvalent, and illuminates two important phenomena. First, the zooarchaeological data from settlement contexts, textile evidence, and the importance of spinning and weaving tools indicate that cloth production was an important aspect of the local economy, both for the production of domestic items and high-quality textiles intended for elite networks of trade and diplomacy. The association between textile equipment and female graves as well as contemporary iconography indicates that this was primarily a female activity. The high numbers of ram's head beads in female graves suggest that sheep imagery indexed cloth production along intersecting gendered, economic, and symbolic lines. Ram's head beads in graves, like textile equipment in the same contexts, may have been an avenue for materializing the importance of textiles and woman-sheep relationships in Dolenjska Hallstatt life. Second, the centrality of Novo mesto in the production and distribution of ram's head beads is significant. The distribution of ram's head beads at sites along the western edge of the Dolenjska region illuminates social networks that connected communities in the later part of the Early Iron Age. Stična, Magdalenska gora, and Novo mesto were large sites that played key roles in trade as well as defence, and the distribution of ram's head beads between them may relate to networks of exchange along the main north-south passage through Dolenjska. However, it is also quite possible that these ram's head beads were moving with the women to whom they belonged. Ties of kinship and the alliances created through strategic intermarriage may have connected sites on the western frontier and these artefact distributions may actually reflect networks of women and their families moving across the landscape. What is clear is that women played an important role in socioeconomic networks of the Early Iron Age, and ram's head beads provide a new lens through which to examine the role of women in this cultural context, even in the absence of written sources. 
ANGEL, J. L. 1968, Human Skeletal Material from Slovenia. - In: H. Hencken (ed.), Mecklenburg Collection, Part I, 73-108, Cambridge, MA.

$A N S l=$ Arheološka najdišča Slovenije 1975. - Ljubljana.

ARAFAT, K., C. MORGAN 1994, Athens, Etruria and the Heuneburg: Mutual misconceptions in the study of Greek-barbarian relations. - In: I. Morris (ed.) Classical Greece: Ancient Histories and Modern Archaeologies, 108-134, Cambridge.

ARNOLD, B. 2005, Mobile men, sedentary women? Material culture as a marker of regional and supra-regional interaction in Iron Age Europe. - In: H. Dobrzańska, V. Megaw, P. Poleska (eds.), Celts on the margin: studies in European cultural interaction, 7th century BC-1st century $A D$ dedicated to Zenon Woźniak, 17-26, Krakow.

BABIĆ, S. 2002, 'Princely Graves' of the Central Balkans - A Critical History of Research. - European Journal of Archaeology 5/1, 70-88.

BAKARIĆ, L., B. KRIŽ, M. ŠOUFEK 2006, Pretpovijesni jantar i staklo iz Prozora u Lici i Novog Mesta u Dolenjskoj / Prehistoric Amber and Glass from Prozor in Lika and Novo Mesto in Dolenjska. - Zagreb.

BARBER, E. W. 1991, Prehistoric Textiles: The Development of Cloth in the Neolithic and Bronze Ages. - Princeton, NJ.

BARBER, E. W. 1994, Women's Work: The First 20,000 Years. Women, Cloth, and Society in Early Times. - New York.

BARTH, F. E. 1969, Die hallstattzeitlichen Grabhügel im Bereiche des Kutscher bei Podsemel (Slowenien). - Antiquitas $3 / 5$.

BARTOSIEWICZ, L. 1991, Faunal Material from Two Hallstatt Period Settlements in Slovenia (Živalski ostanki iz dveh halštatskodobnih naselbin v Sloveniji). - Arheološki vestnik 42, 199-206.

BARTOSIEWICZ, L. 1996, Continuity in the Animal Keeping of Hallstatt Period Communities in Slovenia. - In: E. Jerem, A. Lippert (eds.), Die Osthallstattkultur. Akten des internationalen Symposiums, Sopron, 10.-14. Mai 1994, 29-35, Budapest.

BARTOSIEWICZ, L. 1999, A Systematic Review of Astragalus Finds from Archaeological Sites. - In: A. H. Vaday (ed.), Pannonia and beyond. Studies in honour of László Barkóczi, 37-44, Budapest.

BENDER JØRGENSEN, L. 2005, Hallstatt and La Tène Textiles from the Archives of Central Europe. - In: P. Bichler, K. Grömer, R. Hofmann-de Keijzer, A. Kern, H. Reschreiter (eds.), Hallstatt Textiles: Technical Analysis, Scientific Investigation and Experiment on Iron Age Textiles, BAR. International Series 1351, 133-150.

BICHLER et al. (eds.) 2005 = P. Bichler, K. Grömer, R. H. Hofmann-De Keijzer, A. Kern, H. Reschreiter (eds.) 2005, Hallstatt Textiles: Technical Analysis, Scientific Investigation and Experiment on Iron Age Textiles. BAR. International Series 1351.

BILIĆ, T. 2016, The swan chariot of a solar deity: Greek narratives and prehistoric iconography. - Documenta Praehistorica 43, 445-465.

BOESSNECK, J. 1969, Osteological differences between sheep (Ovis aries Linné) and goat (Capra hircus Linné). - In: D. R. Brothwell, E. S. Higgs (eds.), Science in Archaeology: A Comprehensive Survey of Progress and Research, 311-358, London.
BÖKÖNYI, S. 1974, History of Domestic Mammals in Central and Eastern Europe. - Budapest.

BÖKÖNYI, S. 1994, Analiza živalskih kosti / Die Tierknochenfunde der Siedlung. - In: S. Gabrovec (ed.), Stična I. Naselbinska Izkopavanja / Siedlungsausgrabungen, Katalogi in monografije 28, 190-213.

BONFANTE, L. 1985, Amber, Women, and Situla Art. Journal of Baltic Studies 16/3, 276-291.

BONFANTE, L. 2011, The Etruscan Impact on Ancient Europe. - In: G. R. Tsetskhladze (ed.), The Black Sea, Greece, Anatolia and Europe in the First Millennium BC, 203-231, Leuven, Paris, Walpole, MA.

BOŽIČ, D. 2009, A Hallstatt grave containing a cuirass, excavated near Stična by the Duchess of Mecklenburg in 1913. The reliability of grave groups from the Mecklenburg Collection / K halštatskemu grobu $\mathrm{z}$ oklepom, ki ga je leta 1913 pri Stični izkopala vojvodina Mecklenburška. O zanesljivosti grobnih celot Mecklenburške zbirke. Arheološki vestnik 60, 63-95.

BOŽIČ, D. 2015, Die Situla von Vače gehörte einem Doppelkammhelmträger. - In: C. Gutjahr, G. Tiefengraber (eds.), Beiträge zur Hallstattzeit am Rande der Südostalpen. Akten des 2. Internationalen Symposiums am 10. und 11. Juni 2010 in Wildon [Steiermark / Österreich], Internationale Archäologie. Arbeitsgemeinschaft, Symposium, Tagung, Kongress 19 (Hengist-Studien 3), 107-115.

BOŽIČ, D. 2018, Grave 20 in Tumulus IV: Hallstatt-period burial of a woman at Znančeve njive in Novo mesto / Halštatski ženski grob 20 iz gomile IV na Znančevih njivah v Novem mestu. - Arheološki vestnik 69, 179-207.

BREŠČAK, D. 1982, Veliki Gaber. - Varstvo spomenikov 24, 156-157.

BRUMFIEL, E. M. 2006, Methods in Feminist and Gender Archaeology: A Feeling for Difference - and Likeness. - In: S. M. Nelson (ed.), Handbook of Gender in Archaeology, 31-58, Lanham, MD.

CALDER, L. 2011, Cruelty and Sentimentality: Greek Attitudes to Animals, 600-300 BC. - BAR. International Series 2225.

CASTOR, A. Q. 2016, Etruscan Jewelry and Identity. In: S. Bell, A. A. Carpino (eds.), A Companion to the Etruscans, 275-292, Malden, MA.

CAUSEY, F. 2011, Amber and the Ancient World. - Los Angeles, CA.

CLUTTON-BROCK, J. 1999, A Natural History of Domesticated Mammals. - Cambridge.

CONKEY, M. W., J. D. SPECTOR 1984, Archaeology and the Study of Gender. - Advances in Archaeological Method and Theory 7, 1-38.

DIETLER, M. 1990, Driven by drink: the role of drinking in the political economy and the case of early Iron Age France. - Journal of Anthropological Archaeology 9, 352-406

DOLINAR-OSOLE, Z. 1956, Ilirska okostja iz gomile v Volčjih njivah (The Illyrian Skeletons of Volčje njive). - Arheološki vestnik 7, 131-136.

DULAR, A. 1978, Okras živalskih glav na posodah halštatskega obdobja Slovenije / Tierkopfschmuck auf Gefassen der Hallstattzeit in Slowenien. - Arheološki vestnik 29, 85-94.

DULAR, J. 2003. Halštatske nekropole Dolenjske / Die hallstattzeitlichen Nekropolen in Dolenjsko. - Opera 
Instituti Archaeologici Sloveniae 6. DOI: https://doi. org/10.3986/9789610502944

DULAR, J. 2007, Pferdegräber und Pferdebestattungen in der hallstattzeitlichen Dolenjsko-Gruppe. - In: M. Blečić, M. Črešnar, B. Hänsel, A. Hellmuth, E. Kaiser, C. Metzner-Nebelsick (eds.), Scripta Praehistorica in Honorem Biba Teržan, Situla 44, 737-752.

DULAR, J. 2016, Der eisenzeitliche Zentralort Vače und seine kriegerische Elite / Železnodobno središče Vače in njegova bojevniška elita. - Arheološki vestnik 67, 73-104.

DULAR, J. 2020, Nova spoznanja o poselitvi Dolenjske v starejši železni dobi / On the Early Iron Age Settlement Pattern of Dolenjska. - Arheološki vestnik 71, 395-420.

DULAR, J., B. KRIŽ 1990, Železnodobno naselje in grobišče v Brezjah pri Trebelnem (Die eisenzeitliche Siedlung und Nekropole in Brezje bei Trebelno). - Arheološki vestnik 41, 531-556.

DULAR, J., S. TECCO HVALA 2007, South-Eastern Slovenia in the Early Iron Age. Settlement - Economy - Society / Jugovzhodna Slovenija v starejši železni dobi. Poselitevgospodarstvo - družba. - Opera Instituti Archaeologici Sloveniae 12. DOI: https://doi.org/10.3986/9789612545239

DULAR, J., S. TECCO HVALA (eds.). 2018, Železnodobno naselje Most na Soči. Razprave / The Iron Ige Settlement at Most na Soči. Treatises. - Opera Instituti Archaeologici Sloveniae 34. DOI: https://doi.org/10.3986/9789610501091

DULAR, J., P. PAVLIN, S. TECCO HVALA 2003, Prazgodovinska višinska naselja $\mathrm{v}$ okolici Dol pri Litiji (Vorgeschichtliche Höhensiedlungen in der Umgebung von Dole pri Litiji). - Arheološki vestnik 54, 159-224.

EGG, M. 2010, Gläserne Widderkopfperlen aus der Eisenzeit. - Archäologisches Korrespondenzblatt 40/4, 525-543.

EIBNER, A. 1981, Darstellungsinhalte in der Kunst der Hallstattkultur: Gedanken zum ‘überhöhten' Leben im Situlenbereich und Osthallstattkreis. - In: C. Eibner (ed.), Die Hallstattkultur. Bericht über das Symposium in Steyr 1980 aus Anlaß der Internationalen Ausstellung des Landes Oberösterreich, 261-296, Linz.

EIBNER, A. 1986, Die Frau mit der Spindel. Zum Aussagewert einer archäologischen Quelle. - In: L. Török (ed.), Hallstatt-Kolloquium Veszprém 1984. Mitteilungen des Archäologischen Instituts der Ungarischen Akademie der Wissenschaften, Beiheft 3, 39-48, Budapest.

EIBNER, A. 2005, Wie Wertvoll ist eine Frau? Gedanken zum Stellenwert des Spinnens und Webens in der Gesellschaft. - In: E. M. Feldinger (ed.), Scherben bringen Glück. Festschrift für Fritz Moosleitner zum 70. Geburtstag, 31-38, Salzburg.

EIBNER-PERSY, A. 1980, Hallstattzeitliche Grabhügel von Sopron (Ödenburg). Die Funde der Grabungen 1890-92 in der Prähistorischen Abteilung des Naturhistorischen Museums in Wien und im Burgenländischen Landesmuseum in Eisenstadt. - Wissenschaftliche Arbeiten aus dem Burgenland 62.

FRANKENSTEIN, S., M. J. ROWLANDS 1978, The Internal Structure and Regional Context of Early Iron Age Society in South-Western Germany. - Bulletin of the Institute of Archaeology 15, 73-112.

FRIE, A. C. 2017, Cultural Constructions of Nature: Animal Representation and Use in Early Iron Age Southeastern Slovenia. - PhD Thesis, Milwaukee, University of Wisconsin-Milwaukee (unpublished).
FRIE, A. C. 2018a, Horses and the embodiment of elite masculinity in the Dolenjska Hallstatt culture. - Oxford Journal of Archaeology 37/1, 25-44.

FRIE, A. C. 2018b, Insignia of power: bird imagery on artefacts of hierarchy and ritual in Iron Age Dolenjska (SE Slovenia). - Documenta Praehistorica 45, 166-178.

FRIE, A. C. 2019, Extraordinary Creatures: The Role of Birds in Early Iron Age Slovenia. - Environmental Archaeology 24/4, 400-410.

FRIE, A. C. 2020, Parts and Wholes: The Role of Animals in the Performance of Dolenjska Hallstatt Funerary Rites. - Arts 9/2, 1-25.

GABROVEC, S. 1956, Ilirska gomila v Volčjih njivah (The Illyrian tumulus at Volčje njive). - Arheološki vestnik 7, 62-130.

GABROVEC, S. 1966, Zur Halstattzeit in Slowenien. Germania 44, 1-48.

GABROVEC, S. 1976, Zum Beginn der Hallstattzeit in Slowenien. - In: H. Mitscha-Märheim, H. Friesinger, H. Kerchler (eds.), Festschrift für Richard Pittoni zum siebzigsten Geburtstag, 588-600, Wien, Horn.

GABROVEC, S. 1987, Jugoistočnoalpska regija sa zapadnom Panonijom (Dolenjska grupa). - In: A. Benac (ed.), Praistorija jugoslavenskih zemalja 5. Željezno doba, 29-119, Sarajevo.

GABROVEC, S. (ed.) 2006, Stična II/1. Gomile starejše železne dobe / Grabhügel aus der älteren Eisenzeit. Katalogi in monografije 37.

GASPARI, A. 2007, The Ljubljanica River. Evidence for a Late Iron Age Ritual Site in the South-eastern Alps (Slovenia). - In: S. Groh, H. Sedlmayer (eds.), Blut und Wein. Keltisch-römische Kultpraktiken. Akten des vom Österreichischen Archäologischen Institut und vom Archäologischen Verein Flavia Solva veranstalteten Kolloquiums am Frauenberg bei Leibnitz (Österreich), Mai 2006, 141-154, Montagnac.

GILLIS, C., M.-L. B. NOSCH (eds.) 2007, Ancient Textiles: Production, Craft and Society. - Oxford.

GLEBA, M. 2007, Textile Production in Proto-historic Italy: from Specialists to Workshops. - In: C. Gillis, M.-L. B. Nosch (eds.), Ancient Textiles: Production, Crafts and Society, 71-76, Oxford.

GLEBA, M. 2008, Textile Production in Pre-Roman Italy. - Oxford.

GLEBA, M. 2009, Textile tools and specialisation in Early lron Age female burials. - In: E. Herring, K. Lomas (eds.), Gender Identities in Italy in the First Millennium $B C$, BAR. International Series 1983, 69-78.

GLEBA, M. 2014a, Cloth Worth a King's Ransom: Textile Circulation and Transmission of Textile Craft in the Ancient Mediterranean. - In: K. Rebay-Salisbury, A. Brysbaert, L. Foxhall (eds.), Knowledge Networks and Craft Traditions in the Ancient World Material Crossovers, 83-103, London, New York.

GLEBA, M. 2014b, Italian textiles from prehistory to Late Antique times. - In: S. Bergerbrant, S. H. Fossøy (eds.), A Stitch in Time: Essays in Honour of Lise Bender Jørgensen, 145-169, Gothenburg.

GLEBA, M., U. MANNERING (eds.) 2012, Textiles and Textile Production in Europe from Prehistory to $A D$ 400. - Oxford. 
GLEIRSCHER, P. 2009, Sopron - Nové Košariská - Frög. $\mathrm{Zu}$ den Bildgeschichten der Kalenderberg-Kultur. Praehistorische Zeitschrift 84/2, 202-223.

GOSDEN, C. 1985, Gifts and kin in early Iron Age Europe. - Man 20, 475-493.

GREEN, M. 1992, Animals in Celtic Life and Myth. - London, New York.

GREENFIELD, H. J., E. R. ARNOLD 2008, Absolute age and tooth eruption and wear sequences in sheep and goat: determining age-at-death in zooarchaeology using a modern control sample. - Journal of Archaeological Science 35/4, 836-849.

GRIMALDI, D. A. 1996, Amber: Window to the Past. New York.

GRÖMER, K. 2012, Austria: Bronze and Iron Ages. - In: M. Gleba, U. Mannering (eds.), Textiles and Textile Production in Europe from Prehistory to $A D$ 400, Ancient Textile Series 11, 27-64.

GRÖMER, K. 2016, The Prehistoric Art of Textile Making: The development of craft traditions and clothing in Central Europe. - Vienna.

GRÖMER, K. 2017, Textiles as Early Iron Age prestige goods - a discussion of visual qualities. - In: R. Schumann, S. van der Vaart-Verschoof (eds.), Connecting elites and regions: Perspectives on contacts, relations and differentiation during the Early Iron Age Hallstatt $C$ period in Northwest and Central Europe, 221-236, Leiden.

GRÖMER et al. (eds.) 2013 = K. Grömer, A. Kern, H. Reschreiter, H. Rösel-Mautendorfer (eds.) 2013, Textiles from Hallstatt: weaving culture in Bronze Age and Iron Age salt mines / Textilien aus Hallstatt: gewebte Kultur aus dem bronze- und eisenzeitlichen Salzbergwerk. Budapest.

GRÖMER, K., K. SALIARI 2018, Dressing Central European prehistory - the sheep's contribution. An interdisciplinary study about archaeological textile finds and archaeozoology. - Annalen des Naturhistorischen Museums in Wien, Serie A 120, 127-156.

GRÖMER, K., T. STÖLLNER 2011, Ein abgerissener Ärmel aus dem Salzbergwerk Dürrnberg. Neue erkenntnisse zur Brettchenwebtechnik in der Eisenzeit in Mitteleuropa. - Jahrbuch des Römisch-Germanischen Zentralmuseums Mainz 56 (2009), 105-157.

GRÖMER, K., T. TOLAR, K. KOSTAJNŠEK 2017, Ostanki tekstila in živalskih dlak (krzna) v grobu 6 gomile $1 \mathrm{v}$ Pleški hosti na Molniku / Textile and fur remains in Grave 6, Tumulus 1, from Pleška hosta at Molnik. - In: S. Tecco Hvala (ed.), Molnik pri Ljubljani v železni dobi / The Iron Age site at Molnik near Ljubljana, Opera Instituti Archaeologici Sloveniae 36, 211-223. DOI: https://doi.org/10.3986/9789610503750

GRÖMER et al. 2018 = K. Grömer, K. Kostajnšek, T. Tolar, G. Pajagič Bregar 2018, Tekstilna najdba iz železnodobne naselbine Most na Soči: konservacija, analiza, primerjava / Textile find from the Iron Age settlement at Most na Soči: Conservation, analysis and comparisons. - In: J. Dular, S. Tecco Hvala (eds.), Železnodobno naselje Most na Soči. Razprave / The Iron Age Settlement at Most na Soči. Treatises, Opera Instituti Archaeologici Sloveniae 34, 453-467. DOI: https://doi.org/10.3986/9789610501091

HAEVERNICK, T. E. 1974, Zu den Glasperlen in Slowenien. - Situla 14/15, 61-65.
HALSTEAD, P., V. ISAAKIDOU 2017, Sheep, sacrifices, and symbols: animals in Later Bronze Age Greece. - In: U. Albarella, M. Rizzetto, H. Russ, K. Vickers, S. Viner-Daniels (eds.), The Oxford Handbook of Zooarchaeology, 113-126, Oxford.

HÄNSEL, B. 2012, Zum Aufkommen des Vogelsonnenbarken-Symbols vor der Urnenfelderzeit. - In: R. Kujovský, V. Mitáš (eds.), Václav Furmánek a doba bronzová: zborník k sedemdesiatym narodeninám, 109-117, Nitra.

HELMS, M. W. 1993, Craft and the Kingly Ideal: Art, Trade, and Power. - Austin, TX.

HENCKEN, H. 1978, The Iron Age Cemetery of Magdalenska Gora in Slovenia. - Mecklenburg Collection Papers. American School of Prehistoric Research, Bulletin 32.

HLADÍKOVÁ, K. 2018, Protection of Children? A Case Study from the Early Iron Age Cemetery of Quattro Fontanili, Veii. - Studia Hercynia 22/1, 56-76.

HOFFMANN, H. 1966, Tarentine Rhyta. - Mainz.

HUTH, C., M. KONDZIELLA 2017, Textile symbolism in Early Iron Age burials. - In: R. Schumann, S. van der Vaart (eds.), Connecting elites and regions: perspectives on contacts, relations and differentiation during the Early Iron Age Hallstatt $C$ period in Northwest and Central Europe, 145-160, Leiden.

JOYCE, R. A. 2005, Archaeology of the Body. - Annual Review of Anthropology 34, 139-158.

KAUL, F. 1998, Ships on Bronzes: A Study in Bronze Age Religion and Iconography. - Copenhagen.

KMEŤOVÁ, P. 2013a, 'Masters of Horses' in the West, 'Horse Breeders' in the East? On the Significance and Position of the Horse in the Early Iron Age Communities of the Pannonian Basin. - In: R. Karl, J. Leskovar (eds.), Interpretierte Eisenzeiten. Fallstudien, Methoden, Theorie. Tagungsbeiträge der 5. Linzer Gespräche zur interpretativen Eisenzeitarchäologie, 278-258, Linz.

KMEŤOVÁ, P. 2013b, The Spectacle of the Horse: On Early Iron Age Burial Customs in the Eastern-Alpine Hallstatt Region. - Archaeological Review from Cambridge 28/2, 67-81.

KMEŤOVÁ, P. 2018, 'And four strong-necked horses he threw swiftly on the pyre...' On human-horse relationship in the Early Iron Age Central Europe from the perspective of interregional contacts. - In: P. Pavúk, V. Klontza-Jaklová, A. Harding (eds.), EY $\triangle A I M \Omega N$. Studies in honour of Jan Bouzek. Opera Facultatis philosophicae Universitatis Carolinae Pragensis 18, 267-289.

KMEŤOVÁ, P., S. STEGMANN-RAJTÁR 2014, Zur symbolischen Bestattung von Pferdeschädeln in Gräbern der späten Urnenfelder- und älteren Hallstattzeit (K simboliki konjskih lobanj v grobovih iz poznega žarnogrobiščnega in starejšega halštatskega obdobja). - In: S. Tecco Hvala (ed.), Studia Praehistorica in Honorem Janez Dular, Opera Instituti Archaeologici Sloveniae 30, 149-166. DOI: https://doi.org/10.3986/9789610503651

KNEZ, T. 1986. Novo mesto I: Halštatski grobovi / Hallstattzeitliche Gräber. - Carniola Archaeologica 1.

KRIŽ, B. 1997a, Kapiteljska njiva: Novo mesto. - Novo mesto. KRIŽ, B. 1997b, Novo mesto IV. Kapiteljska njiva Gomila II in gomila III. - Carniola Archaeologica 4.

KRIŽ, B. 2000, Novo mesto V. Kapiteljska njiva Gomila IV in gomila V. - Carniola Archaeologica 5. 
KRIŽ, B. (ed.) 2001, Kelti v Novem mestu / The Celts in Novo mesto. Exhibition catalogue 2002. - Novo mesto.

KRIŽ, B. 2012, Odsevi prazgodovine v bronu. Situlska umetnost Novega mesta / Reflections of Prehistory in Bronze. The Situla Art of Novo mesto. - Novo mesto.

KRIŽ, B. 2013, Novo mesto VII. Kapiteljska njiva. Gomile I, XIV in XV / Kapiteljska njiva. Barrows I, XIV and $X V$. - Carniola Archaeologica 7.

KRIŽ, B. 2017, Jantar - dragulji Baltika v Novem mestu / Amber-jewels of the Baltic in Novo mesto. - Novo mesto.

KRIŽ, B., M. GUŠTIN 2015, Prehistoric Glass from Novo mesto / Slovenia. - In: I. Lazar (ed.), Annales du $19 e$ congrès de l'Association internationale pour l'histoire du verre, Piran, 2012, 48-54, Koper.

KRIŽ, B., P. TURK 2003, Bernstein- und Glasschmuck aus Novo Mesto Slowenien. Sonderausstellung vom 8.5.-2.11. 2003. - Hochdorf, Enz.

KRIŽ, B., P. STIPANČIĆ, A. ŠKEDELJ PETRIČ 2009, Arheološka podoba Dolenjske / The Archaeological Image of Dolenjska. - Novo mesto.

KROMER, K. 1959, Brezje. Halštatske gomile z Brezij pri Trebelnem / Hallstättische Hügelgräber aus Brezje bei Trebelno. - Arheološki katalogi Slovenije 2.

KRUH, A. 2008, Gomila 5 ali Tratarjeva Gomila / Grabhügel 5 oder Tratar-Grabhügel. - In: S. Gabrovec, B. Teržan (eds.), Stična II/2. Gomile starejše železne dobe. Razprave / Grabhügel aus der alteren Eisenzeit. Studien, Katalogi in monografije 38 (2010), 69-131.

KUZMINA, E. 2006, Mythological Treatment of the Horse in Indo-European Culture. - In: S. L. Olsen, S. Grant, A. M. Choyke, L. Bartosiewicz (ed.), Horses and Humans: The Evolution of Human-Equine Relationships, 263-270, Oxford.

LAHARNAR, B. 2018, Kovinske in steklene najdbe ter kamniti kalupi iz železnodobne naselbine na Mostu na Soči / Metal finds, glass finds and stone moulds from the Iron Age settlement at Most na Soči. - In: J. Dular, S. Tecco Hvala (eds.), Železnodobno naselje Most na Soči. Razprave / The Iron Age Settlement at Most na Soči. Treatises. Opera Instituti Archaeologici Sloveniae 34, 195-248. DOI: https://doi.org/10.3986/9789610501091

LAHARNAR, B., P. TURK 2017, Železnodobne zgodbe $s$ stičišča svetov. - Ljubljana.

LAHARNAR, B., P. TURK 2018, Iron Age Stories from the Crossroads. - Ljubljana.

LUCKE, W., O.-H. FREY 1962, Die Situla in Providence (Rhode Island). Ein Beitrag zur Situlenkunst des Osthallstattkreises. - Römisch-Germanische Forschungen 26.

MARTIN, T. F., R. WEETCH 2017, Introduction: Dress and Society. - In: T. F. Martin, R. Weetch (eds.), Dress and Society: Contributions from Archaeology, 1-13. Oxford.

METZNER-NEBELSICK, C. 2007, Pferdchenfibeln. Zur Deutung einer frauenspezifischen Schmuchform der Hallstatt-und Frühlatènezeit. - In: M. Blečić, M. Črešnar, B. Hänsel, A. Hellmuth, E. Kaiser, C. Metzner-Nebelsick (eds.) Scripta Praehistorica in Honorem Biba Teržan, Situla 44, 707-735.

MLEKUŽ, D. 2013, The Birth of the Herd. - Society \& Animals 21/2, 150-161.

MLINAR, M. 2020, Most na Soči. Arheološke raziskave v letih 2000-2016 na levem bregu Idrijce / The 2000-2016 archaeological investigations on the left bank of the
Idrijca. - Opera Instituti Archaeologici Sloveniae 43. DOI: https://doi.org/10.3986/9789610504887

MÜLLER-SCHEEßEL, H. C., P. TREBSCHE 2007, Das Schwein und andere Haustiere in Siedlungen und Gräbern der Hallstattzeit Mitteleuropas. - Germania 85, 61-94.

MURGELJ, I. 2020, Nove risbe figuralnih upodobitev na situlah z Vač in Magdalenske gore ter iz Valične vasi (Revised drawings of the situlae from Vače, Magdalenska gora and Valična vas). - Arheološki vestnik 71, 569-580.

NASH BRIGGS, D. 2003, Metals, Salt, and Slaves: Economic Links Between Gaul and Italy From the Eighth to the Late Sixth Centuries BC. - Oxford Journal of Archaeology 22/3, 243-259.

OELZE et al. 2012 = V. M. Oelze, J. K. Koch, K. Kupke, O. Nehlich, S. Zäuner, J. Wahl, S. M. Weise, S. Rieckhoff, M. P. Richards 2012, Multi-isotopic analysis reveals individual mobility and diet at the early Iron Age monumental tumulus of Magdalenenberg, Germany. - American Journal of Physical Anthropology 148/3, 406-421.

PALAVESTRA, A. 1993, Praistorijski ćilibar na centralnom i zapadnom Balkanu / Prehistoric Amber in central and western Balkans. - Posebna izdanja. Balkanološki institut Srpske akademije nauka i umetnosti 52.

PALAVESTRA, A. 2007, Was there an Amber Route? - In: I. Galanaki, H. Tomas, Y. Galanakis, R. Laffineur (eds.), Between the Aegean and Baltic Seas: Prehistory Across Borders. Proceedings of the International Conference Bronze and Early Iron Age Interconnections and Contemporary Developments between the Aegean and the Regions of the Balkan Peninsula, Central and Northern Europe. University of Zagreb, 11-14 April 2005, 349-356, Liège, Austin.

PARE, C. F. E. 1989, From Dupljaja to Delphi: the ceremonial use of the wagon in later prehistory. - Antiquity 63/238, 80-100.

PAULI, L. 1975, Keltischer Volksglaube: Amulette und Sonderbestattungen am Dürrnberg bei Hallein und im eisenzeitlichen Mitteleuropa. - München.

PAVLOVIČ, D. 2014, Drnovo. - In: B. Teržan, M. Črešnar (eds.), Absolutno datiranje bronaste in železne dobe na Slovenskem / Absolute dating of the Bronze and Iron Ages in Slovenia, Katalogi in monografije 40, 401-504.

PEIRCE, C. S. 2012 [1897], Logic as Semiotic: The Theory of Signs. - In: J. Buchler (ed.), The Philosophical Writing of Peirce, 98-119, New York.

POTREBICA, H. 2012, Religious Phenomena of the Hallstatt Communities of Southern Pannonia. - In: S. Berecki (ed.), Iron Age Rites and Rituals in the Carpathian Basin. Proceedings of the International Colloquium from Târgu Mureș. 7-9 October 2011, 9-29, Târgu Mureș.

PRIMAS, M. 2007, Spinnwirtel im Grab - zum Symbolgehalt einer Beigabe. - In: M. Blečić, M. Črešnar, B. Hänsel, A. Hellmuth, E. Kaiser, C. Metzner-Nebelsick (eds.), Scripta Praehistorica in Honorem Biba Teržan, Situla 44, 301-312.

PRUMMEL, W., H.-J. FRISCH 1986, A Guide for the Distinction of Species, Sex, and Body Side in Bones of Sheep and Goat. - Journal of Archaeological Science 13, 567-577.

RAST-EICHER, A., L. BENDER JØRGENSEN 2013, Sheep wool in Bronze Age and Iron Age Europe. - Journal of Archaeological Science 40, 1224-1241. 
REBAY-SALISBURY, K. 2016, The Human Body in Early Iron Age Central Europe: Burial Practices and Images of the Hallstatt World. - New York, London.

REYNOLDS, P. J. 1987, Ancient Farming. - Princes Risborough.

RYDER, M. L. 1990, Skin, and Wool-Textile Remains from Hallstatt, Austria. - Oxford Journal of Archaeology 9/1,37-49.

SALVAGNO, L., U. ALBARELLA 2017, A morphometric system to distinguish sheep and goat postcranial bones. - PloS ONE 12/6, 1-37.

SLABE, M. 1982, Malo Hudo. - Varstvo spomenikov 24, 151-152.

STARE, F. 1953, Trije prarzgodovinski grobovi iz Zasavja (Drei vorgeschichtliche Gräber aus dem Save-Anraingebiet). - Arheološki vestnik 4, 264-281.

STARE, V. 1964-1965, Železnodobne gomile na Vinkovem vrhu (Eisenzeitliche Grabhügel auf Vinkov vrh). - Arheološki vestnik 15/16, 215-257.

STARE, V. 1973, Prazgodovina Šmarjete (Der vorgeschichtliche Komplex von Šmarjeta). - Katalogi in monografije 10.

STÖLLNER, T. 2005, More than old Rags - Textiles from the Iron Age Salt-mine at the Dürrnberg. - In: P. Bichler, K. Grömer, R. Hofmann-de Keijzer, A. Kern, H. Reschreiter (eds.), Hallstatt Textiles - Technical Analysis, Scientific Investigation and Experiments on Iron Age Textiles, BAR. International Series 1351, 161-174.

ŠKVOR JERNEJČIČ, B., B. TOŠKAN 2018, Ritual use of dogs and wolves in the Late Bronze and Early Iron Age in the South-Eastern Alpine region. New evidence from the archaeo(zoo)logical perspective. - In: S. Costamagno, L. Gourichon, C. Dupont, O. Dutour, D. Vialou (eds.), Animal symbolisé, animal exploité: du Paléolithique à la Protohistoire, 249-278, Paris.

ŠMIT, Ž., B. LAHARNAR, P. TURK, 2020, Analysis of prehistoric glass beads from Slovenia. - Journal of Archaeological Science: Reports 29, 1-13.

TACLA, A. B. 2008, 'Prestation Economy': A model for Late Bronze Age and Early Iron Age burial deposition in Central-Western Europe. - Revista do Museo de Arqueologia e Etnologia 18, 133-153.

TANKO, K. 2005, 'Horn-Handled' Bowls of the Central Europe Iron Age. - In: H. Dobrzańska, V. Megaw, P. Poleska (eds.), Celts on the Margin: Studies in European Cultural Interaction 7th Century BC - 1st Century AD. Dedicated to Zenon Woźniak, 153-162, Kraków.

TECCO HVALA, S. 2007, Women from Magdalenska gora. - In: M. Blečić, M. Črešnar, B. Hänsel, A. Hellmuth, E. Kaiser, C. Metzner-Nebelsick (eds.), Scripta Praehistorica in Honorem Biba Teržan, Situla 44, 93-110.

TECCO HVALA, S. 2012. Magdalenska gora. Družbena struktura in grobni rituali železnodobne skupnosti / Social structure and burial rites of the Iron Age community. Opera Instituti Archaeologici Sloveniae 26. DOI: https:// doi.org/10.3986/9789612546007

TECCO HVALA, S., B. ŠKVOR JERNEJČIČ 2017, Kulturna in družbena identiteta / Cultural and social identities. - In: S. Tecco Hvala (ed.), Molnik pri Ljubljani v železni dobi / The Iron Age Site at Molnik near Ljubljana, Opera Instituti Archaeologici Sloveniae 36, 166-170. DOI: https://doi.org/10.3986/9789610503750

TECCO HVALA, S., J. DULAR, E. KOCUVAN 2004. Železnodobne gomile na Magdalenski gori / Eisenzeitliche
Grabhügel auf der Magdalenska gora. - Katalogi in monografije 36.

TERŽAN, B. 1973, Valična vas. - Arheološki vestnik 24, 660-699.

TERŽAN, B. 1985, Poskus rekonstrukcije halštatske družbene strukture v dolenjskem kulturnem krogu / Ein Rekonstruktionsversuch der Gesellschaftstruktur im Dolenjsko-Kreis der Hallstattzeit. - Arheološki vestnik 36, 77-106.

TERŽAN, B. 1996, Weben und Zeitmessen im südostalpinen und westpannonischen Gebiet. - In: E. Jerem (ed.), Die Osthallstattkultur: Akten des Internationalen Symposiums, Sopron, 10.-14. Mai 1994, 507-536, Budapest.

TERŽAN, B. 2004, L'aristocrazia femminile nella prima eta del Ferro. - In: F. Marzatico, P. Gleirscher (eds.), Guerrieri, principi ed eroi fra il Danubio e il Po dalla Preistoria all'Alto Medioevo, 221-229, Trento.

TERŽAN, B. 2008, Stiške skice / Stična-Skizzen. - V / In: S. Gabrovec, B. Teržan, Stična II/2. Gomile starejše železne dobe / Grabhügel aus der älteren Eisnezeit, Katalogi in monografije 38 (2010) 189-325.

TERŽAN, B. 2012, Sfinga v situlski umetnosti ob severnem Jadranu in njegovem zaledju / The sphinx in Situla Art in the northern Adriatic region and its hinterland. In: B. Migotti, P. Mason, B. Nadbath, T. Mulh (eds.), Scripta in Honorem Bojan Djurić, 170-196, Ljubljana.

TERŽAN, B. 2013, Wasservogelsymbolik in der älteren Hallstattzeit. - In: J. Kolendy, A. Mierzwińskiego, S. Moździocha, L. Żygadło (eds.), Z badań nad kultura społeczeństw pradziejowych i wczesnośredniowiecznych. Ksiega Jubileuszowa dedykowana Profesorowi Bogusławowi Gedidze, w osiemdziesiąta rocznice urodzin przez przyjaciól, kolegów i uczniów, 89-107, Wrocław.

TOŠKAN, B., L. BARTOSIEWICZ 2018, Živalski ostanki iz naselbine na Mostu na Soči: vpogled v družbeno kompleksnost železnodobne skupnosti v jugovzhodnoalpskem prostoru / Animal remains from the settlement at Most na Soči: Insights into social complexity of an Iron Age community in south-eastern Alps. - In: J. Dular, S. Tecco Hvala (eds.), Železnodobno naselje Most na Soči. Razprave / The Iron Age Settlement at Most na Soči. Treatises, Opera Instituti Archaeologici Sloveniae 34, 467-510. DOI: https://doi.org/10.3986/9789610501091

TUCK, A. 2006, Singing the Rug: Patterned Textiles and the Origins of Indo-European Metrical Poetry. - American Journal of Archaeology 110, 539-550.

TURK, P. 2005, Podobe življenja in mita (= Bilder aus Leben und Mythos) (= Images of life and myth). - Ljubljana.

WELLS, P. S. 1981, The Emergence of an Iron Age Economy: The Mecklenburg Grave Groups from Hallstatt and Stična. - Cambridge, MA.

WELLS, P. S. 1985, Socio-economic aspects of the amber trade in Early Iron Age Slovenia. - Journal of Baltic Studies 16/3, 268-275.

WYLIE, A. 20002, Thinking from Things: Essays in the Philosophy of Archaeology. - Berkeley, Los Angeles, CA.

ZEDER, M. A., H. A. LAPHAM 2010, Assessing the reliability of criteria used to identify postcranial bones in sheep, Ovis, and goats, Capra. - Journal of Archaeological Science 37, 2887-2905.

ŽELEZNIKAR, J. (ed.) 1999, Poselitvena podoba Mengša in okolice: od prazgodovine do srednjega veka. - Mengeš. 


\section{Ženske, ovce in tekstil: družbeni pomen jagod v obliki ovnove glavice v starejši železni dobi na Slovenskem}

\section{Povzetek}

Jagode v obliki ovnove glavice so s 187 znanimi primerki najpogostejše zoomorfne najdbe dolenjske halštatske kulture na območju jugovzhodne Slovenije. Temeljno razpravo o njih je napisal Markus Egg, obravnaval jih je $z$ vidikov izdelave, časovne in geografske razsežnosti njihovega pojavljanja ter predlagal tipološko členitev. Njegovo delo ostaja dragocen vir, ki ga $\mathrm{v}$ pričujočem prispevku dopolnjujem s še nekaterimi primerki in podrobnejšo tipologijo. Glavni poudarek v tem prispevku pa je na vprašanju, kakšen je bil lokalni pomen jagod v obliki ovnove glavice, ki je pri Eggu ostalo odprto. ${ }^{1}$

\section{Razprostranjenost jagod v obliki ovnove glavice}

V svoji disertaciji sem obravnavala živalski imaginarij dolenjske halštatske kulturne skupine, pri čemer sem se osredotočila na upodobitve posameznih živalskih vrst in na zvrsti predmetov, ki jih upodabljajo, ter na kontekstualne povezave in odnose med človekom in živalmi, značilne za starejšo železno dobo. ${ }^{2}$ Študija je ob ugotovitvi, da so jagode $v$ obliki ovnove glavice najpogostejše zoomorfne najdbe v tej regiji, potrdila njihov pomen, kot ga je prepoznal Markus Egg. ${ }^{3}$ Doslej so znane iz 17 najdišč (sl. 2), 104 primerki izvirajo iz grobov, 2 sta naselbinski najdbi, 81 je posamičnih najdb iz grobiščnih kompleksov ali pa so konteksti neznani (pril. 1).

Že Egg je jagode v obliki ovnove glavice $\mathrm{z}$ območja Slovenije časovno opredelil v mlajše faze starejše železne dobe in celo $\mathrm{v}$ mlajšo železno dobo. Po lokalni relativni kronologiji za dolenjsko halštatsko kulturno skupino so se pojavile v stopnji certoških fibul in so ostale v uporabi še v stopnji negovskih čelad (tj. od konca 6. do konca 4. st.

\footnotetext{
1 Egg 2010, 539.

2 Frie 2017.

3 Egg 2010.
}

pr. n. št.). ${ }^{4} \mathrm{~V}$ Novem mestu v Kandiji ${ }^{5}$ je bila ena taka jagoda odkrita tudi v grobu iz latenske dobe, zanjo pa se domneva, da jo je v njem pokopana oseba morda podedovala. ${ }^{6}$

Thea Elisabeth Haevernick in pozneje Borut Križ s soavtorji so v svojih študijah nakazali, da bi stilska podobnost in razprostranjenost teh jagod ter množica steklenih najdb nasploh pričali o njihovem izdelovanju v lokalni delavnici nekje na območju današnjega Novega mesta. ${ }^{7}$ Čeprav so jih najbrž izdelovali lokalno, pa novi izsledki kažejo, da so stekleni ingoti oz. steklena masa verjetno prišli z levantskega območja ali morda Egipta. Nedavne analize PIXE, PIGE steklenih najdb iz starejše železne dobe $\mathrm{z}$ območja Dolenjske so namreč pokazale, da gre za natronsko steklo, najbližji viri za zmes natrijevega karbonata in bikarbonata pa so v Egiptu in na Bližnjem vzhodu, ${ }^{8}$ kar dodatno pritrjuje hipotezi Markusa Egga, da so jagode v obliki ovnove glavice na Dolenjskem navdihnili starejši vzhodnosredozemski in egipčanski vzori. ${ }^{9}$

Večina tovrstnih jagod $\mathrm{z}$ območja Dolenjske je steklenih, le pet je jantarnih. ${ }^{10}$ Par jantarnih primerkov je bil pridan v grob VI/4 na Kapiteljski njivi $\mathrm{v}$ Novem mestu, drug tak par je znan iz stiškega groba $5 / 11$, oba pa sta datirana $v$ čas 5. -4 . st. pr. n. št. ${ }^{11}$ Še en jantarni primerek je posamična najdba

4 Ib., 532-535. Za relativno kronologijo glej Teržan 2008, 273-293.

${ }^{5} \mathrm{~V}$ članku uporabljam najdiščno ime Kandija v Novem mestu, ker je širše uveljavljeno kot Znančeve njive, ki se v objavah redkeje pojavlja. Najdišče je pod imenom Znančeve njive zabeleženo $\mathrm{v}$ spletni podatkovni zbirki ARKAS in nekaterih drugih objavah (npr. ANSl 1975; Dular, Tecco Hvala 2007).

${ }^{6}$ Gr. 56: Križ 2001, 164, kat. št. 542; Egg 2010, 533-534.

7 Haevernick 1974; Križ, Turk 2003, 78; Bakarić, Križ, Šoufek 2006, 11; Egg 2010, 534.

8 Šmit, Laharnar, Turk 2020.

9 Egg 2010, 535-539.

10 Ib., 532.

11 Novo mesto - Kapiteljska njiva, gr. VI/4: Križ, Turk 2003, 99, kat. št. 84; Bakarić, Križ, Šoufek 2006, 186, kat. št. 269; Stična, gr. 5/11: Kruh 2008, 99. 
iz gomile VI v Stični. ${ }^{12}$ Edina bronasta jagoda $\mathrm{v}$ obliki ovnove glavice s tega območja izvira iz groba VII/1 na Brezju pri Trebelnem.

Tovrstne jagode lahko pretežno pripišemo ženskam (sl. 3), kajti od spolno opredeljivih kontekstov jih 68 izvira iz 12 ženskih grobov. ${ }^{13}$ Število jagod v posameznih grobovih je zelo različno: v $52 \%$ grobov je bila pridana po ena taka jagoda, v $31 \%$ pa po pet ali več skupaj.

Tipologijo zanje je predložil že Egg; ločeval je med večjimi (do $2,3 \mathrm{~cm}$ dolge) in manjšimi jagodami (v povprečju $1,5 \mathrm{~cm}$ dolžine), slednje je nadalje razdelil v dve skupini - eno predstavljajo jagode valjaste oblike z izstopajočimi pecljatimi očesi, drugo pa bolj kroglaste $\mathrm{z}$ očesi, ki so bila verjetno oblikovana s sekundarno toplotno obdelavo. ${ }^{14} \mathrm{~V}$ tem prispevku predlagana tipologija je bolj podrobna in nekoliko drugačna od Eggove, uporabna pa je tudi v primerih, ko so jagode le fragmentarno ohranjene in ko ni mogoče ugotoviti, ali so bile toplotno obdelane ali ne. Poleg velikosti in oblike se zdi merodajna tudi barvitost, ločevati jih je mogoče na enobarvne in večbarvne, med temi pa še na jagode, ki imajo očesa in nosnice iz dveh, treh ali štirih plasti stekla (glej pril. 1).

12 Wells 1981, 80, 213, Fig. 161i, v prvotni objavi je jagoda napačno označena kot steklena.

$13 \mathrm{Ob}$ tem je treba omeniti, da se ne sklicujem na biološko določen spol, ker se zaradi kisle zemlje v tej regiji kostni ostanki redko ohranijo. Spolna pripadnost je zato opredeljena na podlagi grobnih pridatkov. V redkih primerih ohranjenih kosti pa je osteološka analiza potrdila korelacijo med določenimi predmeti in spolom pokopane osebe oziroma je pokazala, da se biološki in po pridatkih opredeljena spolna pripadnost ujemata, se pravi, da so bili pridatki večinoma razporejeni po binarnem principu (Dolinar-Osole 1956; Gabrovec 1956; 2006; Angel 1968; Hencken 1978; Teržan 1985; Tecco Hvala, Dular, Kocuvan 2004). Študija upodobitev živali v dolenjski halštatski kulturi vključuje številne predmete, na katere se pogosto opira opredelitev spola pokopane osebe (npr. zapestnice in jagode; prim. Teržan 1985; 2008; Tecco Hvala 2012, 376-384). V izogib krožnemu sklepanju pri prepoznavanju spola pokopanih oseb se opiram na bolj konservativen sklop predmetov, in sicer na orožje, obrambne oprave, britve in brusne kamne kot verjetne označevalce moškega spola (Teržan 1985; 2008, 233-245; Tecco Hvala 2012, 137-143, 341) ter na uhane in lasne obročke, nanožnice in tkalske pripomočke za ženskega (Tecco Hvala 2007; 2012, 290, 332-333). V primerih, ko so $\mathrm{v}$ grobu pridatki, značilni za moški in ženski spol, ga obravnavam kot dvojni pokop; če ne vsebujejo nobenega pokazatelja spola, pa kot neopredeljenega. Za podrobnejšo diskusijo o tem glej Frie 2017, 76-80.

14 Egg 2010, 529-531.
Tip 1: velike jagode (vsaj $2 \mathrm{~cm}$ ali večje).

Tip 2: enobarvne jagode (v povprečju velike $1,5 \mathrm{~cm}$ ).

Tip 3: večbarvne jagode:

varianta 3a. $z$ dvoplastnimi očesci in nosnicami: - 3a.i. z izstopajočimi očesci in nosnicami (toplotno neobdelane);

- 3a.ii. s ploskimi ali okroglimi očesci in nosnicami (toplotno obdelane);

varianta 3b. $s$ triplastnimi očesci:

- 3b.i. z izstopajočimi očesci in nosnicami (toplotno neobdelane);

- 3b.ii. s ploskimi ali okroglimi očesci in nosnicami (toplotno obdelane);

varianta $3 c$. $s$ štiriplastnimi očesci:

- 3c.i. z izstopajočimi očesci in nosnicami (toplotno neobdelane);

- 3c.ii. s ploskimi ali okroglimi očesci in nosnicami (toplotno obdelane).

Jagode tipa 1 zaznamuje poleg velikosti tudi njihova raznolikost; ta tip je doslej znan zgolj iz Novega mesta. Jagode tipa 2 so zastopane v manjšem številu v Stični, na Vinkovem vrhu in Kapiteljski njivi v Novem mestu, prednjači pa Valična vas s 35 primerki. Pri tipu 3 ni povsem jasno, ali obstajajo med variantami $3 a, 3 b$ in $3 c$ pomenljive kronološke ali prostorske razlike ali pa je plastovitost očesc in nosnic zgolj slogovna izbira. Večja korelacija med toplotno obdelavo ter tri- in štiriplastnimi očesci in nosnicami se kaže pri variantah $3 b$ in $3 c$; znaki sekundarne toplotne obdelave so opazni pri 25 primerkih variant 3 b.ii in $3 c$.ii in le pri dveh jagodah variante $3 b . i^{15}$ ter eni variante 3 c.i. ${ }^{16}$

Koncentracija različnih tipov je očitna v Novem mestu, kjer so bile najdene vse variante, $\mathrm{z}$ izjemo $3 c . i$, kar govori v prid domnevi, da je bilo tu središče izdelovanja jagod $\mathrm{v}$ obliki ovnove glavice. Odkrite so bile pravzaprav le v dveh gomilah - V in VI na Kapiteljski njivi. Po velikem številu jagod tipa 2 po drugi strani prednjači Valična vas, kar bi lahko bil pokazatelj, da je bil ta tip jagod izdelan kje drugje ali pa da je njihova distribucija potekala po drugih mrežah kot pri ostalih tipih jagod v obliki ovnove glavice.

15 Triplastna očesca in nosnice brez toplotne obdelave imata jagodi iz groba V/40 na Kapiteljski njivi v Novem mestu (Dolenjski muzej P2503).

16 Jagoda s štiriplastnimi očesci in nosnicami brez toplotne obdelave je znana iz Vinice - Stražni dol, gr. 122 (Peabody Museum of Archaeology and Ethnology PM 40-77-40/10977). 
$\mathrm{V}$ grobovih $\mathrm{z}$ več tovrstnimi jagodami skupaj so te, razen v treh primerih, različnih tipov. Dva ali več tipov skupaj je zastopanih v desetih grobovih. Ta heterogeni zbir sestavlja več parov ali skupkov takih jagod, pri čemer ni jasno, ali je bila ta heterogenost zaželena in izkazuje različne mreže distribucije ali delavnice ali pa je šlo za njihovo postopno akumulacijo (npr. da so jih ženske z leti pridobile več, se pravi, starejše ko so bile ženske, več raznovrstnih jagod so zbrale), vendar bi bilo treba ta vzorec še preučiti.

\section{Pomembnost ovac}

Če izvzamemo jagode v obliki ovnove glavice, so druge upodobitve teh živali na Dolenjskem presenetljivo redke. Na Magdalenski gori je med rekonstruiranimi pridatki groba $2 / \mathrm{b}$ par samostrelnih fibul $\mathrm{z}$ zaključkom noge $\mathrm{v}$ obliki naprej gledajoče ovnove glavice, še ena podobna je na tem najdišču zabeležena v grobu X/48. ${ }^{17}$ Ovca/oven je upodobljen samo še na dveh bronastih situlah, ena izvira z Rebri na Vačah, iz groba $1881 / 1,{ }^{18}$ druga s Kapiteljske njive v Novem mestu, iz groba III/12, ${ }^{19}$ znan pa je tudi nenavaden keramični rhyton $\mathrm{v}$ podobi ovna iz groba IV/47 v Stični. ${ }^{20}$

Ta maloštevilen korpus upodobitev ovac/ovnov, če odštejemo jagode, otežuje interpretacijo njihovega pomena. Zdi se, da so imeli predvsem ovni ritualno funkcijo kot žrtvene živali. Na situli iz novomeškega groba III/12 je upodobljen moški z ovco na povodcu, podoben prizor je tudi na situli z Vač, na kateri ovnu sledi moški s sekiro. Drugačne vrste dokaz za žrtvovanje ovac so živalski ostanki drobnice v grobovih. ${ }^{21}$

Poleg tega se ovnom pripisuje simbolni pomen plodnosti v železni dobi v jugovzhodnih Alpah. To domnevo utemeljuje Hrvoje Potrebica $z$ najdbami steklenih in jantarnih jagod v obliki ovnove glavice v ženskih grobovih z območja Hrvaške ter oblikami posod v njihovi podobi, kot so askoi in druge. ${ }^{22}$ Vendar ne pojasni, čemu naj bi bili simbol plodnosti. Brez utemeljitve povezav med simboliko plodnosti in ženskami tvegamo redukcijo vloge žensk v tedanjih

\footnotetext{
17 Hencken 1978, 74, 260, Fig. 298; Tecco Hvala, Dular, Kocuvan 2004, 29, t. 9.

${ }^{18}$ Laharnar, Turk 2017, 100-101, Fig. 111; Frie 2020; Murgelj 2020.

19 Križ 1997, 24-28, App. 3.

20 Wells 1981, 66, 184, Fig. 101.

21 Frie 2020.

22 Potrebica 2012, 13-14.
}

družbah zgolj na rojevanje. ${ }^{23}$ Četudi bi bili povezani z žensko rodnostjo, ostaja odprto vprašanje, zakaj prav ovce oziroma še posebno ovni.

Mitja Guštin in Pasko Kuzman v upodabljanju ovnov prav tako prepoznavata idejo plodnosti, a jo povezujeta z moško plodnostjo in rodnostjo čred, široko razprostranjenost upodobitev ovnov $\mathrm{v}$ južni Evropi pa $z$ mitom o zlatem runu in argonavtih. ${ }^{24}$

Omeniti kaže, da je v upodobitvah mnogokrat težko razločevati ovne od ovc ali skopljenih samcev. Ovni so najbolj izrazito prepoznavni po morfologiji rogov, v upodobitvah imajo nazaj pomaknjene rogove, ki se ovijajo okoli ušes oz. z naprej štrlečimi konci, medtem ko so rogovi pri ovcah sabljaste oblike in niso ukrivljeni naprej kot pri ovnih. Rogati so bili verjetno tudi skopljeni samci, vendar so jim rogovi rasli počasneje in niso bili tako robustni kot pri ovnih.

Povsod po jugovzhodni Evropi so imeli tako ovni kot ovce v tej dobi običajno rogove, a so očitno obstajale tudi variacije, kot kaže arheozoološki zbir $z$ gradišča Cvinger nad Virom pri Stični, v katerem so bili prepoznani tudi neobičajni ostanki ovc brez rogov. ${ }^{25}$ Če rogovi niso ohranjeni, je prepoznavanje spola živali in razlikovanje med ovnom in skopljenim samcem toliko težje, kar enako velja za njihove upodobitve. Številne ovce se v ikonografiji enači z ovni, tudi tu obravnavanim jagodam se enoznačno pripisuje oblika ovnove glavice.

Pogostost teh jagod se sklada $\mathrm{z}$ zastopanostjo ovc $\mathrm{v}$ arheozoološkem zbiru $\mathrm{z}$ dolenjskih utrjenih naselij iz halštatske dobe, ${ }^{26} \mathrm{v}$ okviru katerega so druga ali tretja najpogostejša živalska vrsta, ${ }^{27} \mathrm{kar}$ kaže na njihovo pomembnost $\mathrm{v}$ lokalni samooskrbi kot vira pridelave mesa, mleka, kože in volne.

Podrobnejši podatki o kostnih ostankih ovac so na voljo s prej omenjenega gradišča Cvinger nad Virom pri Stični. Čeprav v večini primerov ni bilo možno določiti biološkega spola, kar bi omogočilo uvid $\mathrm{v}$ demografsko sliko čred ter pomen molže in pridobivanja volne $\mathrm{v}$ odnosu do mesa, pa so bili ugotovljeni ovni in ovce pa tudi skopljeni samci. ${ }^{28}$

${ }^{23}$ Conkey, Spector 1984; Wylie 2002, 185-199; Brumfiel 2006.

24 Guštin, Kuzman (v pripravi).

25 Bökönyi 1974; Bökönyi 1994, 197.

26 Bartosiewicz 1991; 1996; Bökönyi 1994, 196.

${ }^{27} \mathrm{~V}$ arheozooloških analizah običajno ni mogoče razločevati kostnih ostankov ovc od kozjih (Boessneck 1969; Prummel, Frisch 1986; Zeder, Lapham 2010; Salvagno, Albarella 2017), zato je težko ugotoviti, ali drugo mesto pripada ovcam in tretje kozam ali obratno.

28 Bökönyi 1994, 197. 
Čeprav so ti živalski ostanki večidel opredeljeni v mešano kategorijo ovce/koze, pa analize starostnih profilov nakazujejo, da so ovce prvenstveno gojili za mleko in volno in manj za meso, saj so jih zaklali v starosti, ko so imele manjšo kulinarično vrednost. ${ }^{29}$

Bistvena lastnost, po kateri se ovce razlikujejo od drugih domačih živali, je njihovo runo, ki se uporablja kot surovina za izdelavo tkanin. Ker so tkanine hitreje propadajoč material, so v arheoloških kontekstih redko izpričane in $\mathrm{v}$ interpretacijah teh morda celo prezrte. ${ }^{30}$

\section{Volna in ženske}

Pomen izdelovanja tkanin v lokalnem gospodarstvu poudarjajo pogoste najdbe predilnih vretenc v grobnih in naselbinskih kontekstih in malo manj pogoste najdbe uteži za statve in šivank. Nedavne raziskave predrimskega tekstila kažejo, da so ljudje v starejši železni dobi poznali dokaj zapletene vzorce ter načine tkanja in barvanja tkanin. ${ }^{31}$

Večina tekstilnih najdb iz tistega časa je znana iz Sredozemlja ${ }^{32}$ ter rudnikov soli v Hallstattu in Dürrnbergu. ${ }^{33}$ Bolj redki ostanki tkanin z območja Slovenije nakazujejo, da je bilo tudi tu prisotno znanje izdelovanja visokokakovostnih tkanin. Nedavna analiza ohranjenega ostanka tkanine iz groba $1 / 6 \mathrm{v}$ Pleški hosti na Molniku kaže na zelo fino tkanje v vezavi koničastega kepra; preja debeline $0,2 \mathrm{~mm} \mathrm{z}$ gostoto od 28 do 32 niti na cm pa uvršča to tkanje med najfinejše izdelke na območju vzhodnohalštatske kulture. ${ }^{34}$ Drugi ohranjeni ostanki tkanin z območja Slovenije imajo gostoto od 20 do 22 niti na $\mathrm{cm} .{ }^{35}$ Visoka kakovost na tem območju izdelanega tekstila in pogoste najdbe tkalskih in predilskih pripomočkov v naseljih in grobovih pričajo, da je bila izdelava tkanin pomembna lokalna obrt in da so tkanine imele $\mathrm{v}$ obtoku med elito bržkone tudi prestižno in tržno vrednost. ${ }^{36}$

${ }^{29}$ Ib., 202; Green 1992, 11.

30 Gillis, Nosch 2007.

31 Bender Jørgensen 2005; Bichler et al. 2005; Gleba 2007; 2009; Gleba, Mannering 2012; Rast-Eicher, Bender Jørgensen 2013; Grömer 2016; Grömer, Saliari 2018.

32 Prim. Gleba 2008; 2014b.

33 Prim. Ryder 1990; Bichler et al. 2005; Stöllner 2005; Grömer, Stöllner 2011; Grömer 2012; Grömer et al. 2013; Grömer, Saliari 2018.

${ }^{34}$ Grömer, Tolar, Kostajnšek 2017.

35 Bender Jørgensen 2005, kat. št. 98 in 114; Grömer, Tolar, Kostajnšek 2017, 217-218; Grömer et al. 2018, 458-459.

${ }^{36}$ Nash Briggs 2003; Grömer 2017.
Da je bilo predenje in tkanje volne domena žensk, pričajo najdbe predilnih vretenc in tkalskih uteži pretežno $\mathrm{v}$ ženskih grobovih, kot tudi ikonografski motivi, znani z Apeninskega polotoka, ${ }^{37}$ kot denimo na tronu iz groba $89 \mathrm{v}$ Verucchiu, ki prikazuje predenje in tkanje, ${ }^{38}$ ali na bronastem zvoncu iz Bologne - Tomba degli Ori, okrašenem v stilu situlske umetnosti s prizori žensk visokega sloja, ki mikajo volno in jo predejo v niti ter tkejo na dvonadstropnih statvah (sl. 5). ${ }^{39}$ Predice in tkalke so prav tako upodobljene na lončeni posodi iz gomile 27 v Sopronu - Várhely na Madžarskem (sl. 6), ${ }^{40}$ medtem ko so takšne upodobitve v jugovzhodni Evropi redke, kar še ne pomeni, da se tudi tamkajšnje ženske niso ukvarjale $\mathrm{z}$ izdelovanjem tekstila. ${ }^{41}$ Verjetno ne gre zgolj za upodabljanje preprostih ženskih opravil, temveč za dejavnost, ki je bila tesno povezana $\mathrm{z}$ izkazovanjem prestiža, obdarovanjem med elito in $\mathrm{z}$ diplomacijo, predstavljala je nemara tudi pomembno ritualno dejavnost $\mathrm{z}$ bogatimi simbolnimi konotacijami. ${ }^{42}$

Ta različna pričevanja kažejo na korelacijo med ženskami, tekstilom in ovcami. Kot je bilo že prej omenjeno, je bilo na območju dolenjske halštatske kulture najdenih 68 jagod v obliki ovnove glavice v 12 ženskih grobovih, h katerim lahko prištejemo še pet primerkov iz treh dvojnih grobov, ki so vsebovali moške in ženske pridatke, medtem ko so znani samo trije moški grobovi, v katerih je bilo skupno odkritih 12 takih jagod - enajst steklenih in ena bronasta. V skupnem seštevku jagod iz grobnih kontekstov predstavljajo moški grobovi zgolj $12 \%$, ženski pa $65 \%$. Tudi keramični rhyton v podobi ovna iz groba IV/47 v Stični naj bi bil pridan ženski osebi. ${ }^{43}$ Po drugi strani so iz gomil na Magdalenski gori in Grofovih njivah pri Drnovem znani živalski ostanki ovc/koz. ${ }^{44} \mathrm{~V}$ grobu $4 \mathrm{z}$ Grofovih njiv je bila najdena kost zadnje okončine ovce/koze, od drugih pridatkov pa lončenina, tri

37 Bonfante 1985; Eibner 1986; 2005; Barber 1991; 1994; Teržan 1996; 2004; Primas 2007; Gleba 2009; Huth, Kondziella 2017.

38 Gleba 2008, 28-29; Gleba 2009, 69-70, Fig. 1.

${ }^{39}$ Bonfante 1985, 280-281, 283; Bonfante 2011, 207, Fig. 2.

40 Teržan 2004, 223, Fig. 2; Gleirscher 2009, 217, Fig. 8; Bonfante 2011, 206, Fig. 1.

41 Rebay-Salisbury 2016, 110-136, 223-225, 250.

42 Npr. Eibner 1986; 2005; Teržan 1996; Rebay-Salisbury 2016, 223-225.

43 Wells 1981, 66, 184, Fig. 101.

${ }^{44} \mathrm{Iz}$ analize so izključeni tisti živalski ostanki, ki so bili natančneje opredeljeni kot kozji, vključeni pa so tisti, ki so opredeljeni kot ostanki drobnice (ovca/koza). 
certoške fibule, dva obročka, del pasne spone in železna puščična ost, kar kaže na moški pokop. ${ }^{45}$ Od dveh magdalenskogorskih grobov z živalskimi ostanki drobnice je grob $13 / 163^{46}$ verjetno ženski, medtem ko groba VII $/ 29^{47}$ ni mogoče pripisati določenemu spolu. Grob 13/163 je vseboval še koščeno iglo in predilna vretenca, kar podkrepljuje pomenljivost povezave ovc z izdelavo tkanin. Povezave med ženskami in živalskimi ostanki ovc/koz so zaznavne tudi $\mathrm{v}$ drugih sočasnih kulturah na območju srednje Evrope. Nils Müller-Scheeßel in Peter Trebsche ugotavljata, da se v Hallstattu med pridatki v ženskih grobovih pojavljajo ostanki ovc/ koz, v moških pa so bili pridani kosi svinjine. ${ }^{48}$

\section{Jagode v obliki ovnove glavice in tekstilni pripomočki}

Da bi ovrednotili potencialno korelacijo med upodobitvami ovac in izdelovanjem tekstila, smo analizirali še prisotnost predilnih vretenc in tkalskih uteži med pridatki obravnavanih grobov (pril. 2). Devet grobov z jagodami v obliki ovnove glavice, to je tretjina primerov, je vsebovalo tudi pripomočke za izdelovanje tekstila - v osmih primerih predilna vretenca in $\mathrm{v}$ enem še dve uteži za statve. A je pomenljivost 31-odstotne korelacije odvisna od tega, kako pogosto so $\mathrm{v}$ grobovih z obravnavanega območja pridani predilski/tkalski pripomočki. S tem namenom so bili podrobneje analizirani podatki $\mathrm{z}$ objavljenih izkopavanj na Kapiteljski njivi v Novem mestu, ${ }^{49}$ ki je obsežno in dobro raziskano najdišče z veliko koncentracijo jagod v obliki ovnove glavice in kjer je bilo v bližini verjetno tudi proizvodno središče.

Skoraj četrtina grobov iz objavljenih gomil na Kapiteljski njivi vsebuje pripomočke za izdelavo tekstila (sl. 7). Potemtakem je 31-odstotni delež grobov $\mathrm{z}$ jagodami $\mathrm{v}$ obliki ovnove glavice in predilnimi/tkalskimi pripomočki celo nekoliko večji od pričakovanega, če med tema zvrstema predmetov ne bi bilo pomenljive korelacije. To povezavo podpirajo še drugi sočasni grobovi $z$ upodobitvami ali živalskimi ostanki drobnice. Kot že omenjeno, je stiški grob IV/47 z rhytonom v podobi ovnove

45 Pavlovič 2014, 493-4.

46 Tecco Hvala, Dular, Kocuvan 2004, 78-79, t. 123-124; Tecco Hvala 2012, 31, 90, Fig. 36.

${ }^{47}$ Hencken 1978, 56; Tecco Hvala 2012, 30, 90, Fig. 36.

48 Müller-Scheeßel, Trebsche 2007.

49 Križ 1997; 2000; 2013. glave vseboval predilno vretence, ${ }^{50}$ grob $13 / 163 \mathrm{~s}$ Prelog na Magdalenski gori z živalskimi ostanki ovce/koze je poleg tega vseboval še šivanko, ${ }^{51}$ predilno vretence je bilo tudi v grobu 1881/1 z Rebri na Vačah, $v$ katerem je bila najdena bronasta situla $\mathrm{z}$ upodobitvijo ovna kot žrtvene živali poleg drugih pridatkov, značilnih sicer za moške pokope. ${ }^{52} \mathrm{Ne}$ nazadnje sta na Špičastem hribu ležala jagoda $\mathrm{v}$ obliki ovnove glavice in predilno vretence $\mathrm{v}$ isti naselbinski plasti nedaleč narazen (sonda 1, plast 2)..$^{53}$

Četudi ti primeri še ne dokazujejo pomenljivosti povezav med upodobitvami ovac/ovnov in izdelovanjem tekstila, so zagotovo zelo sugestivni. V grobnih kontekstih so imele jagode v obliki ovnove glavice podobno funkcijo kot predilna vretenca - obe vrsti predmetov pa se implicitno navezujeta na volno in izdelavo tkanin ${ }^{54}$ ter glede na kontekste, opredeljene po spolu, implicirata tudi povezavo žensk s tekstilno obrtjo. Enakega pomena pa ni mogoče pripisati jagodam $\mathrm{v}$ obliki ovnove glavice, najdenim $\mathrm{v}$ treh moških grobovih - dveh na Kapiteljski njivi ${ }^{55}$ in enem $z$ Brezja pri Trebelnem. ${ }^{56}$ Slednjemu je pripisana bronasta taka jagoda, ki je bila sekundarno predelana iz zaključka noge figuralne fibule in morda ni imela enake simbolne konotacije kot stekleni primerki; tudi sicer je ta grobni inventar dokaj neobičajen. Jagodi v obliki ovnove glavice iz obeh moških grobov s Kapiteljske njive pa sta stekleni in podobni tistim iz ženskih grobov, kar bi kazalo na to, da take jagode niso omejene zgolj na ženski spol. Ob tem je možnih več razlag, kot denimo, da sta bila ta moška na neki način povezana $\mathrm{z}$ izdelovanjem tekstila ali $\mathrm{z}$ ovcami in $\mathrm{z}$ njihovimi produkti ali pa da sta bili jagodi darilo njunih žalujočih žena. Ob tem je zanimivo, da gre za grobova $\mathrm{z}$ območja Novega mesta, kjer naj bi bilo izdelovalno središče teh jagod, zato je prav tako možna razlaga, da sta bila povezana $\mathrm{z}$ njihovo izdelavo. ${ }^{57}$

${ }^{50}$ Wells 1981, 66, 184, Fig. 101. Ob tem kaže opomniti, da gre za grobno celoto iz Mecklenburške zbirke, ki jo je treba obravnavati s previdnostjo glede na burno preteklost te zbirke - glej Božič 2009; Tecco Hvala 2012, 28.

51 Tecco Hvala, Dular, Kocuvan 2004, 78-79, t. 123-124.

52 Božič 2015; Dular 2016, 92.

53 Dular, Pavlin, Tecco Hvala 2003, 175.

${ }^{54}$ Sensu Peirce 2012: upodobitve ovac/ovnov posredno kažejo na volno in tekstil in so z njima logično povezane.

${ }^{55}$ Gr. VII/28 in XIV/41: Križ, Stipančić, Škedelj Petrič 2009, 257; Križ 2013, 126, 128, 198-199, t. 52-53.

56 Gr. VII/1: Kromer 1959, 61, t. 20; 21; Dular, Križ 1990, 538.

${ }^{57}$ Dokazov za pripisovanje steklarske dejavnosti določenemu spolu sicer ni na voljo. 


\section{Družbeni kontekst jagod v obliki ovnove glavice}

Ob predpostavki, da so bile jagode v obliki ovnove glavice označevalci tekstilne dejavnosti, se je ta funkcija potemtakem izkazovala prvenstveno skozi osebni nakit, kot so ogrlice. Te se pretežno pojavljajo v ženskih grobovih, $\mathrm{v}$ njih pa glavnino zoomorfnih upodobitev predstavljajo prav jagode $\mathrm{v}$ obliki ovnove glavice. ${ }^{58}$ Pojavljajo se v nizih skupaj z drugimi oblikami steklenih in jantarnih jagod (glej pril. 2), kar bi pomenilo, da so bile ogrlice nekakšno sredstvo/medij razkazovanja blagostanja. Nemara je bila prav vizualizacija bogastva namen barvitega okrasja, ki izkazuje uporabo raznobarvnega stekla in tudi dokaj zapletene steklarske postopke. ${ }^{59}$ Tudi oddaljeni izvor steklene mase bi lahko bil kazalnik bogastva in dostopa do mrež trgovanja/menjave na dolge razdalje. ${ }^{60}$ Temu prav tako pritrjujejo jagode iz jantarja, ki je tujerodna tvarina s svojskimi lastnostmi. ${ }^{61}$

Jagode v obliki ovnove glavice se na obravnavanem območju na splošno pogosto pojavljajo skupaj z jantarnimi najdbami. Od 29 zanesljivih grobnih celot $s$ tovrstnimi okrasnimi predmeti jih je kar 22 vsebovalo tudi jantar (76 \%). Če je bilo posedovanje teh jagod povezano s funkcijo $\mathrm{v}$ elitni tekstilni dejavnosti, bi lahko sklepali, da je prav ta dejavnost omogočala ženskam dostop do uvoženih predmetov bodisi $\mathrm{z}$ neposrednim trgovanjem s tekstilom bodisi prek mrež obdarovanja, po katerih je potekala izmenjava tekstilnih in drugih luksuznih izdelkov med elito.

Prav tako bi bilo možno, da je razkazovanje jagod v obliki ovnove glavice posredno ali neposredno označevalo poreklo njihovih lastnic, razprostranjenost teh jagod pa bi tako kazala na mobilnost žensk med lokalnimi skupnostmi oziroma na eksogamne poroke. ${ }^{62} \mathrm{~V}$ Novem mestu, kjer se domneva izdelovalno središče jagod v obliki ovnovih glavic, je opazna njihova koncentracija v gomilah V in VI na Kapiteljski njivi. Glede na to, da so gomile interpretirane kot posamezne družinsko-rodovne skupnosti, ${ }^{63}$ bi lahko v teh

\footnotetext{
58 Frie 2017, 195-198.

59 Križ, Turk 2003; Križ, Guštin 2015.

60 Helms 1993; Šmit, Laharnar, Turk 2020.

61 Helms 1993; Grimaldi 1996, 144; Bakarić, Križ, Šoufek 2006, 13-21; Causey 2011, 37-41.

62 Za diskusijo o železnodobni ženski mobilnosti v srednji Evropi glej Arnold 2005 in Oelze et al. 2012.

${ }^{63}$ Gabrovec 1966; 1987; Teržan 2008; Tecco Hvala 2012.
}

dveh novomeških gomilah videli središče širitve mreže družinskih povezav.

Razprostranjenost obravnavanih jagod odseva tesne vezi Novega mesta s Stično, Magdalensko goro, Valično vasjo in Vinkovim vrhom (glej sl. 2). Povezava med Novim mestom, Stično in Magdalensko goro se zdi logična, saj gre za tri največja in najpomembnejša železnodobna središča $v$ tej regiji. Stroškovna analiza razdalj med dolenjskimi halštatskimi naselji je pokazala, da je glavna pot v smeri sever-jug potekala od Magdalenske gore do Stične in naprej proti Novemu mestu, druga pomembna pot v Novo mesto pa je vodila mimo Valične vasi in Vinkovega vrha. ${ }^{64}$ Teh najdišč na zahodnem delu Dolenjske pa niso povezovale le regionalne poti in geografska lega, temveč tudi njihov domnevno skupen obrambni sistem, ${ }^{65} \mathrm{o}$ čemer naj bi pričali bojevniški grobovi in najdbe iz certoške in negovske stopnje na najdiščih vzdolž reke Krke do Savske ravni, kjer so bile morda nameščene celo vojaške posadke. ${ }^{66}$ Če to drži, bi lahko dodatno pripomoglo h krepitvi tesnih stikov med temi kraji in $\mathrm{k}$ menjavi izdelkov, tudi jagod $\mathrm{v}$ obliki ovnove glavice, bodisi kot trgovskega blaga bodisi z mobilnostjo žensk, ki so jih posedovale.

Iz vsega tega je razviden večplasten pomen jagod v obliki ovnove glavice v dolenjski halštatski kulturi, ki med drugim kažejo na ekonomske vidike identitete žensk v tedanji družbi in na njihovo vpetost prek tekstilnih izdelkov $\mathrm{v}$ trgovske/menjalne mreže na dolge razdalje. ${ }^{67} \mathrm{~V}$ halštatski dobi je elitna ali diplomatska izmenjava daril veljala za pomemben vidik ne le pri navezovanju družbenih stikov z oddaljenimi skupnostmi, temveč tudi kot izkazovanje bogastva in moči. $\mathrm{V}$ te mreže menjav na dolge razdalje, ki so jih domnevno nadzorovali moški, kar jim je dajalo tudi družbeno veljavo, pa niso bili vključeni zgolj importi, ki jim je bilo doslej v raziskavah namenjeno več pozornosti. ${ }^{68}$ Pomembno vlogo so imeli tudi izvozni izdelki, kot so visokokakovostne tekstilije, ki so morda podeljevale poseben družbeni status in ekonomsko moč ženskam, ki so jih izdelovale.

64 Dular, Tecco Hvala 2007, 191-196, 220-222.

65 Zahvaljujem se Boštjanu Laharnarju, kustosu v Narodnem muzeju Slovenije, ki me je opozoril na povezave med temi najdišči.

66 Tecco Hvala 2012, 142-143, 381; Tecco Hvala, Škvor Jernejčič 2017, 129-130.

67 Nash Briggs 2003; Gleba 2009; 2014a; Bonfante 2011; Grömer 2017.

${ }^{68}$ Frankenstein, Rowlands 1978; Gosden 1985; Dietler 1990; Helms 1993; Arafat, Morgan 1994; Tacla 2008. 


\section{Zaključek}

Če zaključimo, pomen upodobitev ovac/ovnov je verjetno polivalenten in osvetljuje vsaj dva pojava. Zooarheološki podatki iz naselbinskih kontekstov, ostanki tkanin in pripomočki za predenje in tkanje kažejo, da je bila izdelava tkanin pomemben vidik lokalnega gospodarstva za pokrivanje domačih potreb, medtem ko bi lahko bil visokokakovostni tekstil namenjen trgovanju in menjavi ali kot diplomatsko sredstvo. Korelacija med pripomočki za izdelovanje tekstila in ženskimi grobovi ter ikonografijo kaže, da je bila to prvenstveno ženska dejavnost $\mathrm{z}$ ekonomsko in simbolno vrednostjo, katere odsev je mogoče videti tudi $\mathrm{v}$ jagodah $\mathrm{v}$ obliki ovnove glavice, zastopanih v ženskem nakitu.

Po drugi strani je pomenljiva osrednja vloga Novega mesta $\mathrm{v}$ proizvodnji in distribuciji jagod v obliki ovnove glavice. Njihova razprostranjenost osvetljuje mrežo stikov in menjave med lokalnimi skupnostmi na zahodnem obrobju dolenjske halštatske skupine v poslednjih fazah starejše železne dobe. Ključno vlogo v tej mreži pa so igrala večja naselja vzdolž poti sever-jug, to so Stična, Magdalenska gora in Novo mesto.

Prav tako je možno, da so se jagode v obliki ovnove glavice razširile $\mathrm{z}$ mobilnostjo žensk. Morda so te skupnosti na zahodni meji Dolenjske krepile medsebojne stike s porokami oz. prek sorodstvenih vezi. Potemtakem bi v razprostranjenosti jagod v obliki ovnove glavice lahko videli odsev mreže mobilnosti žensk in njihovih družin. V družbenoekonomskih omrě̌jih starejše železne dobe lahko ženskam pripišemo pomembno vlogo, ki smo jo $\mathrm{v}$ kontekstu dolenjske halštatske kulture poskušali osvetliti skozi prizmo jagod v obliki ovnove glavice.

Prevod: Sneža Tecco Hvala

Adrienne C. Frie

University of Wisconsin-Oshkosh

Department of Anthropology, Global Religions, and Cultures

Harrington Hall 303b

800 Algoma Boulevard

Oshkosh, WI 54901

USA

friea@uwosh.edu

Illustrations: Fig. 1: (photo: Borut Križ, Dolenjski muzej). - Fig. 4: (photo Uroš Acman, Narodni muzej Slovenije). Fig. 5: (drawing: Vesna Svetličič, Narodni muzej Slovenije). - Fig. 6: (redrawn by author).

Slikovno gradivo: Sl. 1: (foto: Borut Križ, Dolenjski muzej). - Sl. 4: (foto Uroš Acman, Narodni muzej Slovenije). - Sl. 5: (risba: Vesna Svetličič, Narodni muzej Slovenije). - Fig. 6: (preris: avtorica). 